Original paper

DOI: 10.2478/agri-2020-0009

\title{
COMPARATIVE EFFECTS OF DIFFERENT ORGANIC AND INORGANIC FERTILISERS ON SOIL FERTILITY, PLANT GROWTH, SOIL MICROBIAL COMMUNITY, AND STORAGE ABILITY OF LETTUCE
}

\author{
MOHAMED M. EL-MOGY ${ }^{*}$, SUZY M. ABDELAZIZ², ABDEL WAHAB M. MAHMOUD ${ }^{1}$, \\ TAREK R. ELSAYED ${ }^{1}$, NOHA H. ABDEL-KADER ${ }^{1}$, MOHAMED I. A. MOHAMED ${ }^{1}$
}

\author{
${ }^{1}$ Cairo University, Giza, Egypt \\ ${ }^{2}$ Agriculture Research Centre, Giza, Egypt
}

EL-MOGY, M. - ABDELAZIZ, S.M. - MAHMOUD, A.W.M. - ELSAYED, T.R. - ABDEL-KADER, N.H. - MOHAMED, M.I.A.: Comparative effects of different organic and inorganic fertilisers on soil fertility, plant growth, soil microbial community, and storage ability of lettuce. Agriculture (Pol'nohospodárstvo), vol. 66, no. 3, pp. 87-107.

\begin{abstract}
The current study was conducted to assess whether organic fertilisation could replace mineral fertilisation in lettuce production without adverse effects on yield, quality, and postharvest behaviour. The effect of either mineral or organic fertiliser on soil fertility or the microbial community was also studied. Control plots were fertilised with recommended rates of mineral fertiliser (150: 45: $65 \mathrm{~kg} / \mathrm{haNPK}$ ) and the other treatments were $15 \mathrm{t} / \mathrm{ha}$ compost, $10 \mathrm{t} / \mathrm{ha}$ rabbit manure, and $10 \mathrm{t} / \mathrm{ha}$ chicken manure. Our results indicated that all sources of organic fertiliser significantly increased total nitrogen, organic carbon, total fungi, and bacteria contents of soils compared with mineral fertiliser. Rabbit and chicken manure fertilisers resulted in a significant increase in yield. Compared with conventional fertiliser and other organic treatments, plots receiving rabbit manure showed a lower weight loss and microbial load on fresh lettuce head. Moreover, rabbit manure significantly reduced polyphenol oxidase and peroxidase activity. Hence, these results suggest that rabbit manure fertiliser could be an alternative to conventional production without significant reduction in yield and with low enzymatic browning and better storability.
\end{abstract}

Key words: Lactuca sativa, conventional fertiliser, plant performance, enzymatic browning, storage behavior, soil properties

In the Mediterranean region, the overuse of chemical fertiliser application to increase crop productivity caused several soil problems, such as structure deterioration, organic matter reduction, fertility declination, physicochemical plus microbial changes, erosion, and groundwater pollution (Liang et al. 2013; Montemurro et al. 2010; Meena et al. 2016). For this reason, organic fertilisers have been suggested by many researchers as an efficient alternative (Pradeepkumar et al. 2017; Cervera-Mata et al.
2018). Organic fertilisers are commonly applied instead of mineral fertilisers to enhancing the sustainable agricultural ecosystems without affecting the yield and quality (Hernández et al. 2016; Abuarab et al. 2019). Furthermore, the demand for organic fertilisers increased due to increasing organic markets of vegetables annually worldwide (Chatterjee et al. 2014). Likewise, the organic fertilisers show various benefits including restoring, maintaining, and/or improving physicochemical and biological

Mohamed M. El-Mogy (*Corresponding author), Mohamed I.A. Mohamed, Vegetable Crops Department, Faculty of Agriculture, Cairo University, 12613 Giza, Egypt. E-mail: elmogy@agr.cu.edu.eg

Suzy M. Abdelaziz, Department of Cross Pollinated Vegetable Crops, Agriculture Research Centre, Giza, Egypt Abdel Wahab M. Mahmoud, Plant Physiology Department, Faculty of Agriculture, Cairo University, 12613 Giza, Egypt Tarek R. Elsayed, Department of Microbiology, Faculty of Agriculture, Cairo University, 12613 Giza, Egypt Noha H. Abdel-Kader, Soil Department, Faculty of Agriculture, Cairo University, 12613 Giza, Egypt 
functions of soil, enhancing soil sanitation, improving crop production, and reducing gas emission of greenhouse (Hernández et al. 2014; Shehata et al. 2017).

In the Mediterranean region, the huge quantity of organic wastes, deposited annually from the agrofood industry (Fernández-Hernández et al. 2014), can be exploited as sources for supplying a significant amount of organic matter, macro-, and micronutrients. This would improve soil fertility and plant growth (Ayyobi et al. 2014; Abdeldaym et al. 2019). Besides, these wastes contain bioactive compounds that can improve the suppression capacity against soil-borne diseases and Phyto-parasitic nematode (Abdeldaym et al. 2012; Abdeldayem et al. 2014; Federica et al. 2017; Asses et al. 2018; Atia et al. 2020).

One of the popular fresh-leafy vegetable crops belonging to the Asteraceae family is lettuce ( $\mathrm{Lac}$ tuca sativa L.). Lettuce was cultivated intensively in the Mediterranean region. In 2015, lettuce recorded the maximum production of 2.4 million tons in Spain, Italy, France, Germany, and Egypt (FAOSTAT 2015). However, the crop was considered one of the most perishable leafy crops due to high water content and the sensitivity to microbial infections (Martinez-Romero et al. 2008).

Several pre-harvest factors affect the postharvest quality of crops such as fertilisation, irrigation, and abiotic stress (Shehata et al. 2019; Tudela et al. 2013; Viacava et al. 2018; El-Mogy et al. 2018; Vwioko et al. 2019). Mineral and organic fertilisers showed different influences on postharvest quality due to their different characteristics (Mahmoud et al. 2019). Mditshwa et al. (2017) reported that the nutrients, that release organic fertilisers slower than mineral ones, are the main factor affecting nutrients availability. Thus, the plants' physiological processes affect different crop quality parameters under organic and conventional systems. For instance, Paoletti (2015) recorded that the effect of the source of nitrogen (either organic or mineral) on the organoleptic attributes of crops edible parts. Reganold et al. (2010) and Khalil and Hassan (2015) concluded that postharvest quality parameters of many crops grown changed significantly between conventionally and organically managed soils. Many pre- and postharvest factors influenced firmness, soluble solids con- tent, titratable acidity, nutritional content, pigments, colour, aroma, and microbial content (Oliveira et al. 2012; Alam et al. 2014; El-Mogy et al. 2019a). In this study, we compared composted farmyard wastes, rabbit and chicken manure (the main lowcost organic fertilisers in the Egyptian local environment) with mineral fertilisers. This study also investigated the influence of either organic or conventional fertilisation on soil chemical and microbial properties, yield quality parameters of lettuce heads at harvest time, and storage behaviour during refrigerated storage at $2^{\circ} \mathrm{C}$ for 28 days.

\section{MATERIAL AND METHODS}

\section{Open field experiment setup and treatments}

The field experiment was conducted at the Agricultural Experimental Station, Faculty of Agriculture, Cairo University, Egypt (latitude $30.0131^{\circ} \mathrm{N}$, longitude $31.2089^{\circ} \mathrm{E}$, and $694 \mathrm{~m}$ ). Lettuce (Evram cv) was evaluated during two successive winter seasons (from October until December of 2016 and 2017). The soil of the experimental area was ploughed at $30 \mathrm{~cm}$ depth. Then, soil samples were collected at the experiment beginning from each plot at $25 \mathrm{~cm}$ depth to identify the soil physicochemical and microbial properties (Table 1). The treatments included applications of three organic fertilisers to be compared to mineral ones. The following treatments were evaluated: i) control with mineral fertiliser application equal to $150 \mathrm{~kg} / \mathrm{ha} \mathrm{N}, 45 \mathrm{~kg} / \mathrm{ha} \mathrm{P}_{2} \mathrm{O}_{5}, 65$ $\mathrm{kg} / \mathrm{ha} \mathrm{K}_{2} \mathrm{O}$ (recommended by the Agricultural Extension Office of Egyptian Agricultural Ministry); ii) $15 \mathrm{t} / \mathrm{ha}$ of compost generated from farmyard; iii) $10 \mathrm{t} / \mathrm{ha}$ of rabbit manure, and iv) $10 \mathrm{t} / \mathrm{ha}$ of chicken manure. The same organic fertilisers amounts were added twice every year (2016 and 2017) according to the chemical analysis (Table 3 ). The organic fertilisers were added before planting inside the rows. All organic fertilisers were obtained from Agricultural Experimental Station, Cairo University, Giza, Egypt. The chemical analysis and the available elements of all organic fertiliser are presented in Tables 2 and 3. The seed of lettuce was sown by hand in foam trays ( 209 wells) filled with peat moss and vermiculite $(1: 1, \mathrm{v}: \mathrm{v})$ in a plastic greenhouse and irrigated daily. Lettuce seedlings were 
transplanted in the field at 40 days after sowing. Plot area was $4 \mathrm{~m}^{2}$. The space between plants was $20 \mathrm{~cm}$ and between rows was $70 \mathrm{~cm}$. The plants were surface drip-irrigated following transplanting and continued through the experiment at a 15-day interval. Lettuce plants were harvested on the $30^{\text {th }}$ of December. After harvesting, soil samples were taken for the determination of changes in soil chemical properties after mineral and organic fertiliser applications.

\section{Soil sampling and soil physicochemical analysis}

Soil samples were collected using an auger, following a $\mathrm{W}$ scheme to observe any variation in chemical properties, soils were sampled before cultivation (T0 and T2 for 2016 and 2017, respectively) and after harvest (T1 and T3 for 2016 and 2017, respectively). Four samples were taken at $25 \mathrm{~cm}$ depth from each plot after removing the weeds and $5 \mathrm{~cm}$ of soil surface. Air-dried samples of soil were sieved $2 \mathrm{~mm}$. For the physicochemical analysis, soil texture, $\mathrm{pH}$ $(1: 2.5, \mathrm{w} / \mathrm{v})$, electrical conductivity $(\mathrm{EC} 1: 2, \mathrm{w} / \mathrm{v})$, total Kjeldahl nitrogen $(\mathrm{TKN})$, mineral Nitrogen $\left(\mathrm{N}_{\min }\right)$, soil organic carbon content (SOC) and available Phosphorus (P) of soil were determined by analytical methods (Abdeldaym et al. 2012). The exchangeable Calcium $\left(\mathrm{Ca}_{\mathrm{ex}}\right)$ and Potassium $(\mathrm{K})$ content was determined by atomic absorption and was extracted with an alkaline solution ( $\mathrm{pH} 8.2)$ containing on $\mathrm{BaCl}_{2}(10 \%)$ and triethanolamine $(22.5 \mathrm{~mL} / \mathrm{L})$. Also, available Zinc $\left(\mathrm{Zn}_{\mathrm{av}}\right)$ and Iron $\left(\mathrm{Fe}_{\mathrm{av}}\right)$ were determined by using atomic absorption (Pye Unicam, model SP1900, US).2.3.

\section{Chemical analysis of organic fertilisers}

Representative samples were taken randomly from plants and organic fertilisers. Both materials

$\mathrm{T}$ a

Physicochemical and biological properties of soils before experiment in 2016 and 2017

\begin{tabular}{|c|c|c|}
\hline Parameter & 2016 & 2017 \\
\hline Clay [\%] & 29.00 & 29.00 \\
\hline Sand $[\%]$ & 45.00 & 45.00 \\
\hline Silt $[\%]$ & 26.00 & 26.00 \\
\hline $\mathrm{pH}\left[1: 2.5 \mathrm{H}_{2} \mathrm{O}\right]$ & 7.55 & 7.76 \\
\hline $\mathrm{EC}[\mathrm{dS} / \mathrm{m}]$ & 0.41 & 0.37 \\
\hline O.C $[\%]$ & 0.92 & 0.82 \\
\hline O.N [\%] & 0.14 & 0.13 \\
\hline $\mathrm{C} / \mathrm{N}$ ratio & 6.57 & 6.31 \\
\hline $\mathrm{N}_{\min }[\mathrm{mg} / \mathrm{kg}]$ & 43.13 & 23.37 \\
\hline T.Fe $[\%]$ & 4.43 & 4.34 \\
\hline $\mathrm{T} . \mathrm{Zn}[\mathrm{mg} / \mathrm{kg}]$ & 73.40 & 56.50 \\
\hline $\mathrm{P}_{\mathrm{av}}[\mathrm{mg} / \mathrm{kg}]$ & 81.70 & 68.80 \\
\hline $\mathrm{Ca}_{\mathrm{ex}}[\mathrm{cmol} / \mathrm{kg}]$ & 16.32 & 17.50 \\
\hline $\mathrm{K}_{\mathrm{ex}}[\mathrm{cmol} / \mathrm{kg}]$ & 2.57 & 2.41 \\
\hline $\mathrm{Fe}_{\mathrm{av}}[\mathrm{mg} / \mathrm{kg}]$ & 4.38 & 3.69 \\
\hline $\mathrm{Zn}_{\mathrm{av}}[\mathrm{mg} / \mathrm{kg}]$ & 2.08 & 2.31 \\
\hline Total cultivatable bacteria $[\mathrm{CFU} / \mathrm{g}]$ & 7.93 & 8.87 \\
\hline Total cultivatable fungi $[\mathrm{CFU} / \mathrm{g}]$ & 3.96 & 4.30 \\
\hline
\end{tabular}

O.C - organic Carbon; O.N - organic Nitrogen; $\mathrm{N}_{\min }-$ mineral Nitrogen; T.Fe - total Ferric; T.Zn - total Zinc; $\mathrm{P}_{\text {av }}-$ available Potassium; $\mathrm{Ca}_{\mathrm{ex}}$ - exchangeable Calcium; $\mathrm{K}_{\mathrm{ex}}-$ exchangeable Potassium; $\mathrm{Fe}_{\mathrm{av}}-$ available Iron; $\mathrm{Zn}_{\mathrm{av}}-$ available Zinc 
were air-dried, ground, and analyzed according to Trinchera et al. (2006). For the organic fertilisers, the $\mathrm{pH}$ and $\mathrm{EC}$ were determined using $\mathrm{pH}$ and $\mathrm{EC}$ meters in aqueous solutions of the fertilisers with $3: 50, \mathrm{w} / \mathrm{v}$, and $1: 10 \mathrm{w} / \mathrm{v}$, respectively (Italian Official Methods for Fertiliser Analysis, 2002). The Springer-Klee based method (Ciavatta et al. 1989) was used for assessing the organic carbon (OC). Total N (TN) and mineral Nitrogen $\left(\mathrm{N}_{\min }\right)$ were determined using the Kjeldahl method. Available $\mathrm{P}\left(\mathrm{P}_{\mathrm{av}}\right)$ was assessed using the Olsen method. The available nutrients, like exchangeable Potassium $\left(\mathrm{K}_{\mathrm{ex}}\right)$, exchangeable Calcium $\left(\mathrm{Ca}_{\mathrm{ex}}\right)$, available Ferric $\left(\mathrm{Fe}_{\mathrm{av}}\right)$, and available Zinc $\left(\mathrm{Zn}_{\mathrm{av}}\right)$, were measured on the air-dried samples using atomic absorption spectrophotometer with air-acetylene, fuel.

\section{Chemical analysis of lettuce plants}

For the lettuce samples, the total nitrogen content was determined using the modified micro-Kjeldahl method as described by A.O.A.C (1990). Total Phosphorus (T.P) was determined calorimetrically by using the chlorostannous molybdophosphoric blue colour method in sulphuric acid according to Jackson (1973). Total Potassium (T.K) and Calcium (T.Ca) contents were determined using the flame photometer apparatus (CORNING M 410, Germany). Total
Ferric (T.Fe) and Zinc (T.Zn) concentrations were determined using an atomic absorption spectrophotometer with air-acetylene, fuel.

\section{Plant growth and yield traits}

Plant growth traits were measured at harvest time. Fifteen lettuce heads were selected randomly from each experimental unit to measure head fresh weight, head diameter, stem diameter, root weight, and SPAD reading (SPAD 502 Minolta Co, Japan).

\section{Post-harvest evaluation}

After 75 days from transplanting, the completely formed lettuce heads were harvested randomly from each plot. The outer leaves were trimmed and packed individually in a polypropylene stretch and film and refrigerated stored at $2^{\circ} \mathrm{C}$ and $95 \% \mathrm{RH}$ for 28 days. Six heads were used per replicate with three replicates. The following parameters were taken weekly.

\section{Weight loss}

Five lettuce heads were used from each treatment to measure the percentage of weight loss. The weight loss was assessed by the detection of weekly variations in the weight of the stored plants until the end of the shelf life. The following equation is a mathematical representation of the weight loss according to El-Mogy el al. (2019b).

$\mathrm{T}$ a $\mathrm{b} 1 \mathrm{e}$ e 2

Chemical properties of organic fertilisers used in experiment during growing seasons 2016 and 2017

\begin{tabular}{|c|c|c|c|c|c|c|}
\hline \multirow{2}{*}{ Analyses } & \multicolumn{3}{|c|}{2016} & \multicolumn{3}{|c|}{2017} \\
\hline & Rabbit & Chicken & Compost & Rabbit & Chicken & Compost \\
\hline $\mathrm{pH}\left[3: 50 \mathrm{H}_{2} \mathrm{O}\right]$ & 7.40 & 6.30 & 7.20 & 7.60 & 6.42 & 7.15 \\
\hline $\mathrm{EC}[\mathrm{dS} / \mathrm{m}]$ & 1.98 & 2.58 & 1.48 & 1.76 & 2.44 & 1.38 \\
\hline O.C $[\%]$ & 27.40 & 19.90 & 16.93 & 27.30 & 17.31 & 18.00 \\
\hline T.N [\%] & 1.60 & 1.35 & 1.22 & 1.40 & 1.70 & 1.08 \\
\hline $\mathrm{C} / \mathrm{N}$ ratio & 17.10 & 14.70 & 13.90 & 19.50 & 10.20 & 16.70 \\
\hline T.P [\%] & 1.40 & 0.94 & 0.81 & 0.72 & 0.69 & 0.59 \\
\hline T.K [\%] & 1.10 & 0.74 & 0.62 & 0.98 & 0.69 & 0.58 \\
\hline T.Ca $[\%]$ & 1.29 & 1.02 & 0.97 & 1.57 & 1.00 & 0.94 \\
\hline $\mathrm{T} . \mathrm{Zn}[\mathrm{mg} / \mathrm{kg}]$ & 188.10 & 153.70 & 140.40 & 177.60 & 154.50 & 149.10 \\
\hline T.Fe $[\mathrm{mg} / \mathrm{kg}]$ & 814.20 & 597.30 & 645.70 & 799.70 & 633.20 & 731.30 \\
\hline
\end{tabular}

O.C - organic Carbon; T.N - total Nitrogen; T.P - total Phosphor; T.K - total Potassium; T.Ca - total Calcium; T.Zn - total Zinc; T.Fe - total Iron 
$\left[\right.$ Weight loss $\left.[\%]=\frac{\text { Initial weight }- \text { Final weight }}{\text { Initial weight }} \times 100\right]$

\section{Browning index}

The browning of stems was targeted by visual assessment and scored according to the following scale: 1 for no browning, 2 for slight browning, 3 for moderate browning, and 4 for severe browning.

\section{Microbiological analysis}

From each material (soil, organic fertiliser, and plants), reprehensive samples were collected and kept in the refrigerator at $5^{\circ} \mathrm{C}$ for 3 days. These samples were used for the microbial analyses of the total fungi and bacteria. Determination of fecal coliform, serial dilution were inoculated into $\mathrm{MB}$ medium and incubated for 48 hours at $44.5^{\circ} \mathrm{C}$. The results were recorded as positive when the colour of the medium turned into yellow and a notable amount of gas was trapped in the tubes (Rowse 1981). To obtain the total viable bacterial and fungal counts, $5 \mathrm{~g}$ from lettuce leaves were transferred to $50 \mathrm{ml}$ falcon tubes in $30 \mathrm{ml}$ of $0.85 \% \mathrm{NaCl}$ and mixed vigorously for $1 \mathrm{~min}$. Serial dilutions were plated onto nutrient agar medium to determine the total viable bacterial count. Besides, utilization of the Potato Dextrose Agar (PDA) medium supplemented with $200 \mu \mathrm{g} / \mathrm{ml}$ ampicillin for total fungal counts. Counts of colonyforming units (CFU) were estimated after 3 days of incubation at $28^{\circ} \mathrm{C}$. For bulk soil and rhizosphere samples, $5 \mathrm{~g}$ of soil or root samples were placed in $50 \mathrm{ml}$ falcon tubes with a $45 \mathrm{ml} 0.85 \% \mathrm{NaCl}$ and mixed using vortex for $1 \mathrm{~min}$.

\section{Browning enzymes of lettuce plants (Polyphenol} oxidase and peroxidase)

Browning enzymes were determined in the head tissue of lettuce. The peroxidase extraction methods were performed as described by Bestwick et al. (1998) with minor modification. Frozen samples were hydrated overnight with $0.8 \mathrm{~mL}$ of sodium phosphate buffer $(100 \mathrm{mM}, \mathrm{pH} 7)$ at $4{ }^{\circ} \mathrm{C}$. The mixture was homogenized, then, centrifuged at 18,000 $\mathrm{rpm}$ for $20 \mathrm{~min}\left(4^{\circ} \mathrm{C}\right)$. The concentration of protein was assessed according to Bradford et al. (2019). Peroxidase activity was measured with guaiacol at $470 \mathrm{~nm}$ using a spectrophotometer (UV - visible light). Polyphenol oxidase activity (PPO) was

$\mathrm{T}$ a

Amount of elements supplied by different organic fertilisers based on dry weight (DW)

\begin{tabular}{|l|r|r|r|r|r|c|}
\hline \multirow{2}{*}{\multicolumn{1}{|c|}{ Parameter }} & \multicolumn{2}{|c|}{ First growing season $(2016)$} & \multicolumn{2}{c|}{ Second growing season (2017) } \\
\cline { 2 - 7 } & $\begin{array}{c}\text { Rabbit } \\
\text { manure }\end{array}$ & $\begin{array}{c}\text { Chicken } \\
\text { manure }\end{array}$ & $\begin{array}{c}\text { Composted } \\
\text { farm yard } \\
\text { wastes }\end{array}$ & $\begin{array}{c}\text { Rabbit } \\
\text { manure }\end{array}$ & $\begin{array}{c}\text { Chicken } \\
\text { manure }\end{array}$ & $\begin{array}{c}\text { Composted } \\
\text { farm yard } \\
\text { wastes }\end{array}$ \\
\hline Moisture content [\%] & 16.20 & 10.10 & 36.10 & 9.30 & 12.20 & 43.10 \\
Applied rates [t/ha] & 10.00 & 10.00 & 15.00 & 10.00 & 10.00 & 15.00 \\
DW of applied rates [t/ha] & 8.38 & 8.99 & 9.585 & 9.07 & 8.78 & 8.535 \\
EC [dS/m] & 7.30 & 6.00 & 7.20 & 8.20 & 5.70 & 11.50 \\
O.C [kg/ha] & $2,296.10^{\mathrm{a}}$ & $1,789.00^{\mathrm{b}}$ & $1,622.70^{\mathrm{c}}$ & $2,476.10^{\mathrm{a}}$ & $1,519.80^{\mathrm{b}}$ & $1,536.30^{\mathrm{b}}$ \\
T.N [kg/ha] & $134.10^{\mathrm{a}}$ & $121.40^{\mathrm{b}}$ & $116.90^{\mathrm{b}}$ & $154.20^{\mathrm{a}}$ & $122.90^{\mathrm{b}}$ & $92.20^{\mathrm{c}}$ \\
T.P [kg/ha] & $87.20^{\mathrm{a}}$ & $84.50^{\mathrm{a}}$ & $77.60^{\mathrm{a}}$ & $65.30^{\mathrm{a}}$ & $60.50^{\mathrm{a}}$ & $51.01^{\mathrm{a}}$ \\
T.K [kg/ha] & $92.18^{\mathrm{a}}$ & $66.17^{\mathrm{b}}$ & $59.33^{\mathrm{b}}$ & $88.89^{\mathrm{a}}$ & $60.58^{\mathrm{b}}$ & $49.50^{\mathrm{b}}$ \\
T.Ca [kg/ha] & $108.10^{\mathrm{a}}$ & $91.70^{\mathrm{b}}$ & $93.00^{\mathrm{b}}$ & $142.40^{\mathrm{a}}$ & $87.80^{\mathrm{b}}$ & $80.20^{\mathrm{b}}$ \\
T.Zn [g/ha] & $1,576.30^{\mathrm{a}}$ & $1,381.80^{\mathrm{b}}$ & $1,345.70^{\mathrm{b}}$ & $1,610.80^{\mathrm{a}}$ & $1,356.50^{\mathrm{b}}$ & $1,272.60^{\mathrm{c}}$ \\
T.Fe [g/ha] & $6,823.00^{\mathrm{a}}$ & $5,369.70^{\mathrm{b}}$ & $6,189.00^{\mathrm{a}}$ & $7,253.30^{\mathrm{a}}$ & $5,559.50^{\mathrm{c}}$ & $6,241.60^{\mathrm{b}}$ \\
\hline
\end{tabular}

DW - dry weight; EC - electrical conductivity; O.C - organic Carbon; T.N - total Nitrogen; T.P - total Phosphor; T.K total Potassium; T.Ca - total Calcium; T.Zn - total Zinc; T.Fe - total Iron

Values within each row followed by the same letter are not significant according to Tukeytest $(P \leq 0.05 \%)$ 
assessed according to Cao et al. (2009). A $1.5 \mathrm{~mL}$ aliquot of the enzyme extract was gentility mixed with Sodium phosphate buffer (200 mM, pH 6.5) and $1.4 \mathrm{~mL}$ of catechol $(500 \mathrm{mM})$ incubated in a water bath at $30^{\circ} \mathrm{C}$ for $35 \mathrm{~min}$. The spectrophotometer used for this analysis was set at a wavelength equal to $420 \mathrm{~nm}$. The specific activity was expressed as $\mu \mathrm{mol}$ catechol $/ \mathrm{min} / \mathrm{mg}$ protein.

\section{Statistical analysis}

The experiment was designed as a completely randomized block with four replications for each treatment. The analysis of variance (ANOVA) and means were applied by the Tukeytest $(P<0.05)$ using SPSS software (Ver. 19, SPSS Inc., and Chicago, IL). Principal component analysis (PCA) was used to illustrate the associations between observed variables and a new set of non-correlated parameters (variables).

\section{RESULTS AND DISCUSSION}

\section{A general overview of the soil and organic fertilisers properties}

The soil of the experimental field was characterized by clay-loam (sand 45\%, silt 26 and clay $29 \%$ ), according to texture classification of Indorante et al. (1990), low organic carbon, low EC values (Dellavalle 1992), and alkaline $\mathrm{pH}(\mathrm{pH}=7.9)$ which was associated by the small number of cations. For the chemical properties of the applied organic fertilisers, Table 2 shows neutral $\mathrm{pH}$ (between 6.3 and 7.4) and low EC value (between 1.38 and 2.58 $\mathrm{dS} / \mathrm{m})$. The rabbit manure revealed the highest OC (27.4 and $27.3 \%$, first and second year, respectively) and $\mathrm{N}$ content $(1.6 \%$ and $1.4 \%$, first and second year, respectively). The compost and chicken manures contained lower contents of macronutrients in comparison with the rabbit manure.

Table 3 presents the calculated amounts of elements supplied to the soil by organic fertiliser based on the fertiliser dry weight. The rabbit manure supplied the highest amount of organic carbon and total elements in comparison to chicken manure and composted farmyard wastes. However, for the T.P, similar amounts were calculated for the three fertilisers. Chicken manure and composted farmyard wastes supplied lower amounts of T.N and T.Zn during the second season (2017), while a higher amount of T.Fe was supplied during both seasons.

\section{Effect of different organic fertilisers on soil $\mathrm{pH}$ and EC}

After two growing seasons, there were no changes in soil $\mathrm{pH}(\sim 7.67$ in all plots) resulted from applying organic or mineral fertilisation (Figure 1A). The buffer capacity of the alkaline soil, together with, the relatively short time of the lettuce growth cycle could be the main reason for the $\mathrm{pH}$ stability (Hernández et al. 2016). This is supported by the findings of Abdeldaym et al. (2018) who found stable soil $\mathrm{pH}$ under the application of different organic fertilisers. Nonetheless, Abbasi et al. (2015) confirmed that the long period of organic fertiliser application changes the soil $\mathrm{pH}$.

The EC values were ranged between 0.37 and $0.42 \mathrm{dS} / \mathrm{m}$ at the beginning of the experiment. A significant increase was recorded in the plots fertilised by chicken and rabbit manures at the end of the season (Figure 1B). In particular, EC values ranged between 0.75 and $0.87 \mathrm{dS} / \mathrm{m}$ and between 0.72 and $0.90 \mathrm{dS} / \mathrm{m}$ at the end of 2016 and 2017, for chicken and rabbit manure, respectively. The detected increase of soil salinity was possibly due to the application rates and EC values of rabbit and chicken fertilisers (Tables 2 and 3), compared to the compost (Abdeldayem et al. 2018). Similar results were found by Adande et al. (2017), and Azeez and Van Averbeke (2012). The later found that poultry and goat manures increased soil EC due to the increase in the ratio of dissolved salts. However, since the EC values of soil fertilised with organic fertilisers were inferior to the critical level ( $4 \mathrm{dS} / \mathrm{m})$, no prospective threat can be expected to lettuce growth (Tartoura et al. 2014).

\section{Effect of different organic fertilisers on SOC and SON contents}

Data in Figure 1C and 1D shown that no significant differences were observed in soil organic carbon (SOC) and soil organic nitrogen (SON) contents after applying mineral and organic fertilisers at the beginning of 2016 and 2017 seasons (T0 and T2). The differences were recorded by the end of 2016 and 2017 seasons, (T3 and T4). The treatments of organic fertilisers resulted in higher carbon and ni- 
trogen content. The highest values of SOC and SON contents were recorded for plots that received rabbit fertiliser followed by chicken manure and compost compared to mineral fertilisers at T1 and T3 (Figure $1 \mathrm{C}$ and $\mathrm{D})$. Figure 1D shows that the addition of organic fertilisers increased SON content during the sampling times (T1 and T3). However, no significant changes in SON content were recorded for plots fertilised by chicken and composted farmyard wastes during the 2016 season. During the 2017

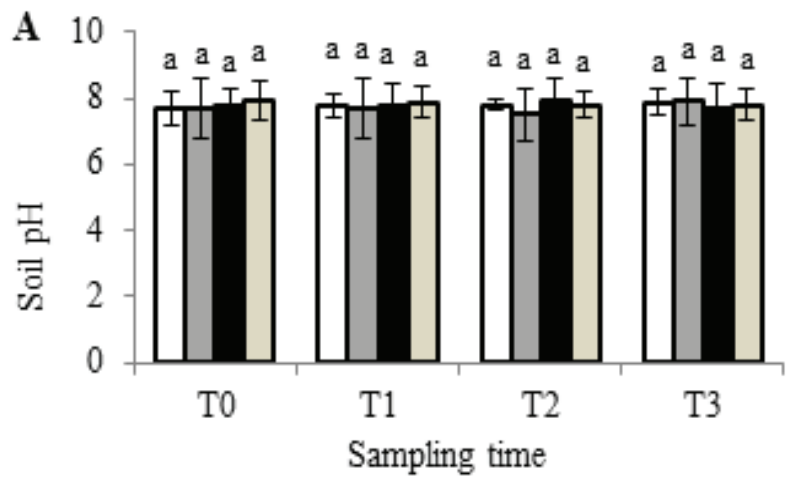

口MIN QCHI $\square$ RAB 口COM

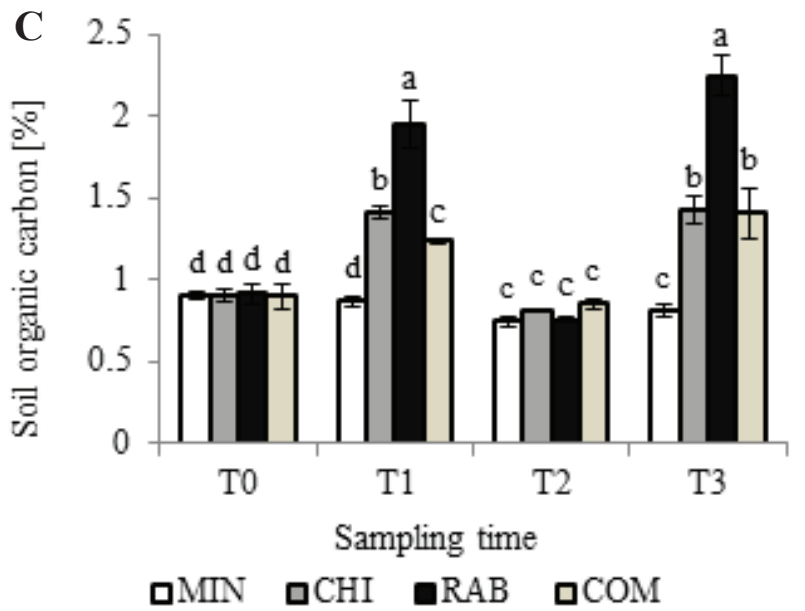

E

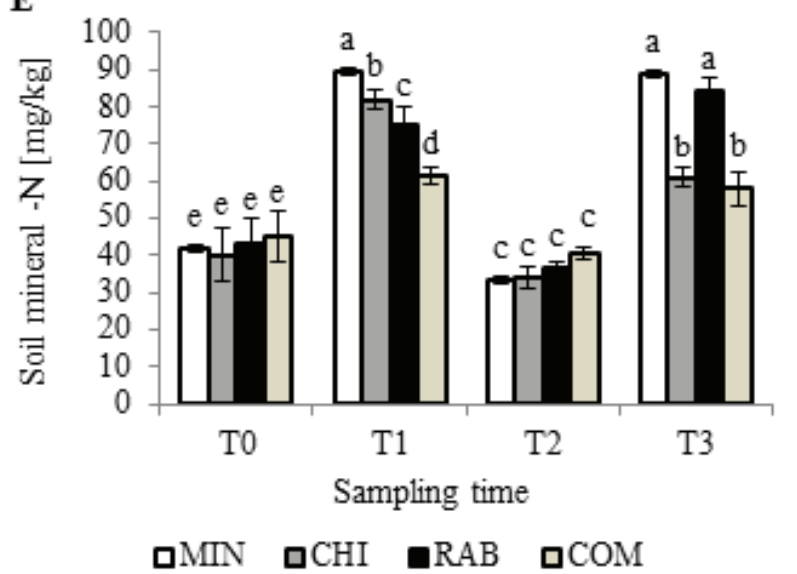

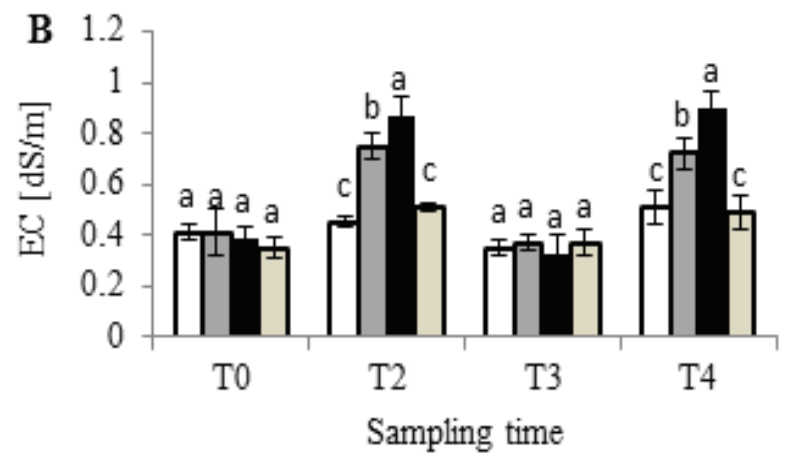

口MIN QCHI $\because \mathrm{RAB} \quad \mathrm{CCOM}$
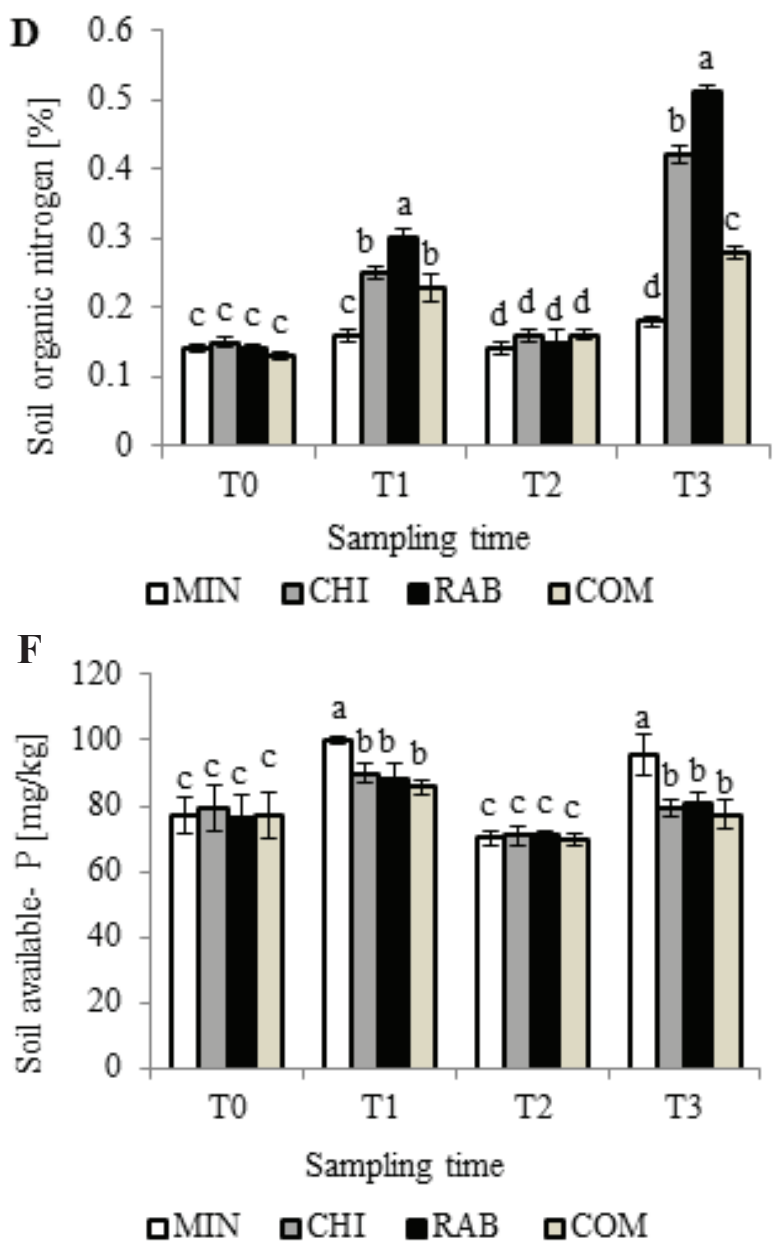

Figure 1. Effect of mineral fertilisers (MIN), chicken manure (CHI), rabbit manure (RAB), and compost (COM). A - soil pH; B - soil EC; C - soil organic carbon; D - soil organic nitrogen; E - soil total mineral nitrogen; F - soil available phosphorus content $(\mathrm{P})$ at different sampling times (T0 \& T2 indicate to initial, T1 \& T3 indicate to end of trials). Columns with the same letters are not significantly different according to Tukeytest $(P \leq 0.05)$. Bars are indicating to standard error (SE). 
season, the chicken manure significantly increased SON content than composted farmyard manure ( $p \leq 0.05$, Figure 1D). Plots fertilised with mineral fertiliser had the lowest SON and SOC contents compared with plots that fertilised with organic fertilisers at T1 and T3 (Figure 1C and 1D). Accumulation of SOC and SON in soil was not only based on $\mathrm{C}$ : $\mathrm{N}$ ratio of organic matter but also on the quality of the labile source of $\mathrm{C}$ and $\mathrm{N}$ inputs (Table 3 ). The highest values of SOC and SON were recorded in treatments fertilised with rabbit manure due to the higher $\mathrm{C}$ : $\mathrm{N}$ ratio (Table 2). This has resulted in a lower mineralization rate of the organic fertilisers (Burger \& Venterea 2008; Apesteguiaa et al. 2018) in contrast to chicken manure and the compost. Similarly, the quality of organic matter of organic fertilisers played a key role in SOC and SON stocks. SOC and SON were largely influenced by exogenous organic $\mathrm{C}$ and $\mathrm{N}$ as well as the available forms of $\mathrm{N}$. The application of organic fertilisers with recalcitrant organic compounds, such as cellulose, hemicellulose, lignin, and other resistant substrates, could result in higher time for degradation and transformation of organic matter into the soil, and it leads to increasing the SOC and SON (Campitelli et al. 2012; Abdeldaym et al. 2018; Chen et al. 2018). By contrast, the application of available $\mathrm{N}$, as high rates of slurries and chicken manures, can promote the rapid degradation of organic matter, promoting the reduction in contents of SOC and NOC (Angers et al. 2011). Thus, it is worth mentioning that incorporation of fresh organic wastes with $\mathrm{C}$ : $\mathrm{N}$ ratio higher than soil $\mathrm{C}: \mathrm{N}$ ratio and composted organic manures, i.e. chicken and rabbit manures, improved the SON and SOC contents (Abdeldaym et al. 2014; Adande et al. 2017).

\section{Effect of different organic fertilisers on soil $N_{\text {min }}{ }^{\prime} P_{a v^{\prime}}$} $C a_{e x}$ and $K_{e x}$ contents

Statistical analysis showed that the application of different fertilisers had significant effects on $\mathrm{N}_{\text {min }}$, $\mathrm{P}_{\mathrm{av}}$ contents (Figure $1 \mathrm{E}$ and $1 \mathrm{~F}$ ) $\mathrm{K}_{\mathrm{ex}}$ and $\mathrm{Ca}_{\mathrm{ex}}$, contents (Figure 2A and 2B). The initial values of soil $\mathrm{N}_{\text {min }}$ content were low at $\mathrm{T} 0$ and $\mathrm{T} 2$ and increased in plots fertilised by mineral and rabbit fertilisers at $\mathrm{T} 1$ and T3 (2016 and 2017). At T1, the highest value of $\mathrm{N}_{\min }$ was recorded in plots fertilised by mineral fertilisers. The concentration of $\mathrm{N}_{\text {min }}$ in plots fertilised by chicken manure was higher than those fertilised by rabbit manure and compost during 2016 (T1). Besides, a negative correlation between the $\mathrm{C}: \mathrm{N}$ ratio and $\mathrm{N}_{\text {min }}$ content of organic fertilisers $(r=0.87)$ were observed. The reduction of soil $\mathrm{N}_{\min }$ content in plots fertilised by chicken manure was observed during 2017 as compared to 2016 (Figure 1E). Such reduction could be correlated to the $\mathrm{C}: \mathrm{N}$ ratio (Table 2) and a higher mineralization rate (Table 3). Several reports confirmed that the lower C: $\mathrm{N}$ ratio of organic fertilisers induced nitrogen loss by nitrification and immobilization, as well as ammonia volatilization (Burger \& Venterea 2008).

The highest value of soil $\mathrm{P}_{\text {av }}$ content was observed after the application of mineral fertiliser $(100.02 \pm 2.8$ and $95.5 \pm 2.1 \mathrm{mg} / \mathrm{kg}$ for $\mathrm{T} 1$ and T3, respectively). Similar findings were recorded for soil $\mathrm{Ca}_{\mathrm{ex}}$ and $\mathrm{K}_{\mathrm{ex}}$ contents. The maximum values of $\mathrm{Ca}_{\text {ex }}$ and $\mathrm{K}_{\text {ex }}$ were observed in plots fertilised with mineral fertilisers and rabbit manures compared to compost and chicken manure. The improvement in soil $\mathrm{P}$ and $\mathrm{Ca}$ content could be attributed to the low solubility of superphosphate fertiliser and the slow release of nutrients $(\mathrm{P}$ and $\mathrm{Ca})$. However, treatments with organic fertilisation added to the soil higher contents of phosphorus concerning mineral fertilisation (Table 3).

Regarding rabbit fertiliser, significant improvement in soil $\mathrm{Ca}_{\mathrm{ex}}$ and $\mathrm{K}_{\mathrm{ex}}$ concentrations could be explained by the amount of organic $\mathrm{Ca}$ and $\mathrm{K}$ supplied from organic fertilisers (Table 3). Also, the organic acids released from the organic fertilisers facilitated dissolving soil nutrients and increasing their availability for the crops (Mondal et al. 2015). Cherney et al. (2002) indicated that manures of high elements content increased soil extractable $\mathrm{K}$ and $\mathrm{Ca}$ even after short time application ( 2 years) in clay soil. Furthermore, the mineralization rate of organic manure and the possibility of soil N, K, and Ca accumulation are based on the manure type and soil properties (Egrinya-Eneji et al. 2003; Hernández et al. 2016).

In general, Figure $2(\mathrm{C}$ and $\mathrm{D})$ shows that the organic fertilisers improved $\mathrm{Zn}_{\mathrm{av}}$ and $\mathrm{Fe}_{\mathrm{av}}$ contents over the two seasons of the experiment. Particularly, the soil was characterized by lower $\mathrm{Zn}_{\mathrm{av}}$ and $\mathrm{Fe}_{\mathrm{av}}$ contents at $\mathrm{T} 0$ and $\mathrm{T} 2$ than $\mathrm{T} 1$ and $\mathrm{T} 3$. This increase 
was a direct result of applying the organic fertilisers in comparison with mineral fertilisers. However, the highest increase in $\mathrm{Zn}_{\mathrm{av}}$ and $\mathrm{Fe}_{\mathrm{av}}$ contents, observed at $\mathrm{T} 1$ and $\mathrm{T} 3$, was of rabbit manure, followed by chicken manure and compost. For chicken manure and compost, a similar increase in $\mathrm{Zn}_{\mathrm{av}}$ and $\mathrm{Fe}_{\mathrm{av}}$ contents was observed over 2016. Nonetheless, chicken manure had higher $\mathrm{Zn}_{\mathrm{av}}$ and lower $\mathrm{Fe}_{\mathrm{av}}$ contents, over 2017, than compost.
The different increases in $\mathrm{Zn}_{\mathrm{av}}$ and $\mathrm{Fe}_{\mathrm{av}}$ contents, observed for each organic fertiliser, can be contributed to their different composition. Indeed, the investigated correlations between total $\mathrm{Zn}$ and Fe contents of the organic fertilisers and $\mathrm{Zn}_{\mathrm{av}}$ and $\mathrm{Fe}_{\mathrm{av}}$ contents of the soil showed high correlation coefficients ( $r=0.6$ and in the case of $\mathrm{Zn}$ and $\mathrm{Fe}$ respectively). Tables 2 and 3 show that rabbit manure contents supplied the highest total $\mathrm{Zn}$ and Fe
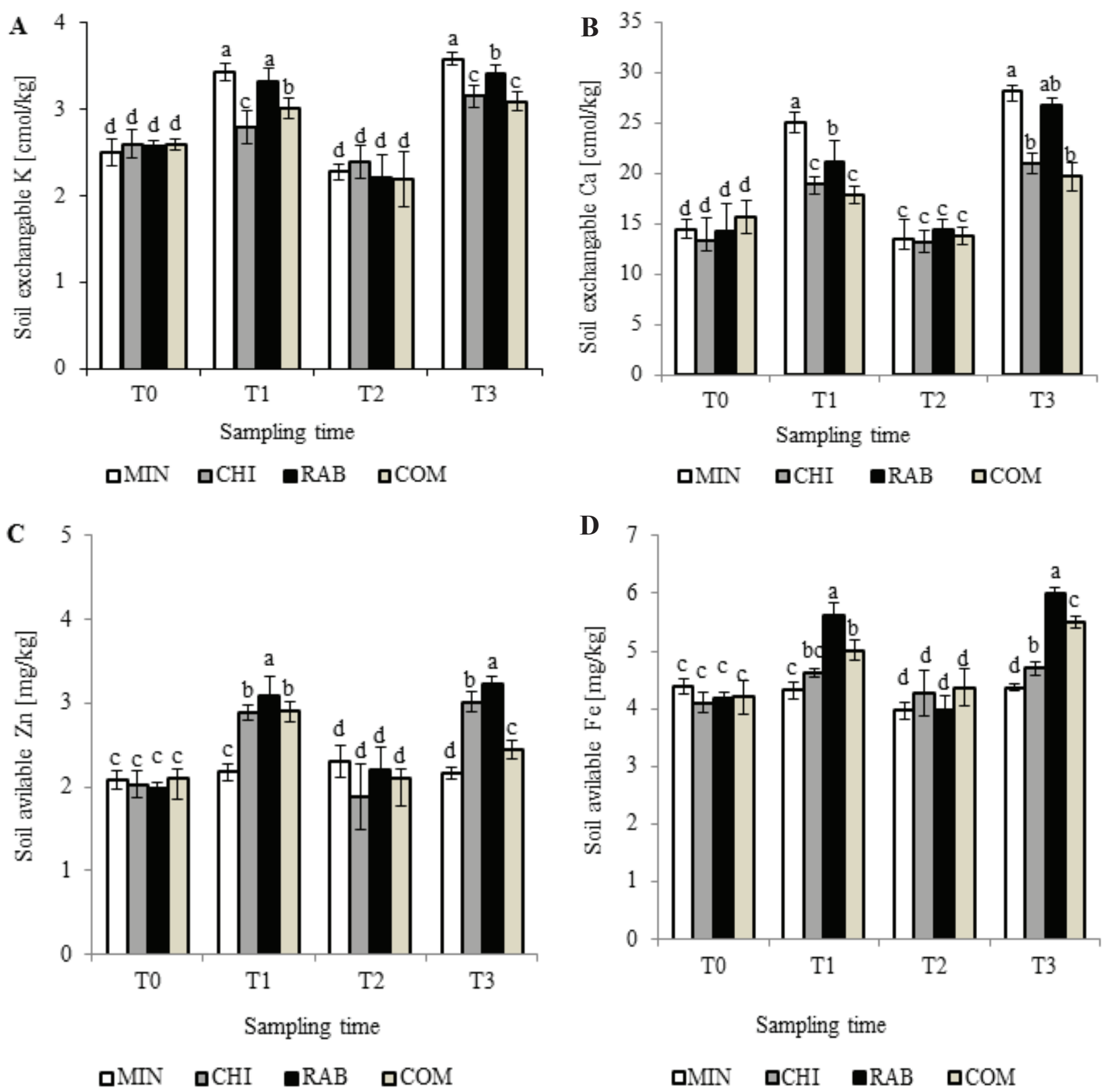

Figure 2. Effect of mineral fertilisers (MIN), chicken manure (CHI), rabbit manure (RAB), and compost (COM). A - soil exchangeable K; B - soil exchangeable Ca; $\mathrm{C}$ - soil available $\mathrm{Zn}$; D - soil available Fe at different sampling times (T0 \& T2 indicate to initial, T1 \& T3 indicate to end of trials). Columns with the same letters are not significantly different according to Tukeytest $(P \leq 0.05)$. Bars are indicating to standard error $(\mathrm{SE})$. 
followed by chicken manure and compost. Organic fertilisers have an important influence on the biological and chemical reactions due to the elements high content in a way increasing the available $\mathrm{Zn}$ and Fe (Shahid et al. 2016). Also, Rutkowska et al. (2014) stated that long-term application of organic fertilisers can alter soil characteristics (e.g. pH and microorganisms) and, therefore, lead to soil richness in available forms of macronutrients regulating the availability of micronutrients to plants.

\section{Effect of different organic fertilisers on soil micro- bial content}

Figure 3A shows soil cultivable fungi and bacteria content over time in various treatments. For all sampling times, soil cultivable fungi and bacteria significantly increased with the addition of organic fertilisers against chemical fertilisers $(p<0.05)$. The microbiological analysis of lettuce plants grown under different fertilisation regimes showed significantly different population densities (Figure 3B and C). A significantly higher bacterial population were detected in the rhizosphere of lettuce plants fertilised by rabbit, compost, and chicken manure (Log CFU counts $=9.03 \pm 0.01,9.04 \pm 0.01$, and $8.99 \pm 0.05$, respectively). In contrast, lettuce plants fertilised by compost fertilisers were characterized by the highest fungal population ( $\log \mathrm{CFU}$ counts $=4.71 \pm 0.03$ ). However, in the second season, the highest bacterial population was detected in the rhizosphere of lettuce plants fertilised by chicken manure (Log CFU counts $=5.72 \pm 0.11$ and $4.81 \pm 0.12$, respectively). Notably, all used organic fertilisers also improved the density of cultivatable bacteria, cultivated fungi in root rhizosphere, and soil microbial content, in comparison to chemical fertilisers. These findings might be associated with amounts of organic carbon in various organic fertilisers (Chakraborty et al. 2011; Amalraj et al. 2013). This implies that root exudates and organic fertilisers are considered a source of sufficient carbon enriching the microorganism biomass and its activity (Liu et al. 2010; Hernández et al. 2016). Similar results were also observed in an open field experiment conducted by Zhen et al. (2014), who found that total microbial biomasses significantly increased different organic fertiliser incorporation. It is worth mentioning that high levels of precautions should be considered when applying fertilisers that might contain fecal and urine, such as chicken and rabbit manure. That is because of the high possibility of contaminating vegetable leaves with pathogenic bacteria (e.g. fecal coliforms) which sicken the final consumer (Oliveira et al. 2012).

$\mathrm{T}$ a b 1 e 4

Effect of mineral fertiliser (MIN), chicken manure (CHI), rabbit manure (RAB), and compost (COM) on total endogenous nutrient contents of lettuce head in 2016 and 2017 at harvest time. Data are mean of $4 \pm$ SE replicates. Values within each row followed by the same letter are not significant according to Tukeytest $(P \leq 0.05 \%)$

\begin{tabular}{|l|c|c|c|c|c|c|}
\hline \multirow{2}{*}{ Fertiliser } & T.N $[\%]$ & T.P $[\%]$ & T.K $[\%]$ & T.Ca $[\%]$ & T.Fe $[p p m]$ & T.Zn [ppm] \\
\cline { 2 - 7 } & \multicolumn{5}{|c|}{2016} \\
\hline MIN & $5.45 \pm 0.05^{\mathrm{a}}$ & $0.70 \pm 0.09^{\mathrm{a}}$ & $6.95 \pm 0.08^{\mathrm{a}}$ & $4.25 \pm 0.13^{\mathrm{a}}$ & $57.55 \pm 0.66^{\mathrm{c}}$ & $162.70 \pm 4.09^{\mathrm{c}}$ \\
RAB & $5.15 \pm 0.20^{\mathrm{ab}}$ & $0.52 \pm 0.08^{\mathrm{ab}}$ & $6.60 \pm 0.23^{\mathrm{ab}}$ & $3.85 \pm 0.22^{\mathrm{ab}}$ & $78.07 \pm 6.78^{\mathrm{a}}$ & $186.60 \pm 3.52^{\mathrm{a}}$ \\
COM & $4.40 \pm 0.17^{\mathrm{b}}$ & $0.41 \pm 0.01^{\mathrm{c}}$ & $5.50 \pm 0.05^{\mathrm{c}}$ & $2.15 \pm 0.03^{\mathrm{b}}$ & $71.30 \pm 105.83^{\mathrm{ab}}$ & $179.75 \pm 9.43^{\mathrm{ab}}$ \\
CHI & $4.70 \pm 0.11^{\mathrm{b}}$ & $0.61 \pm 0.01^{\mathrm{b}}$ & $6.30 \pm 0.05^{\mathrm{b}}$ & $2.05 \pm 0.12^{\mathrm{b}}$ & $67.30 \pm 3.42^{\mathrm{b}}$ & $171.38 \pm 3.3^{\mathrm{b}}$ \\
\hline Fertiliser & \multicolumn{7}{|c|}{2017} & \\
\hline RIN & $5.80 \pm 0.40^{\mathrm{a}}$ & $0.55 \pm 0.01^{\mathrm{a}}$ & $6.41 \pm 0.16^{\mathrm{a}}$ & $5.72 \pm 0.02^{\mathrm{a}}$ & $46.60 \pm 2.11^{\mathrm{c}}$ & $169.50 \pm 1.05^{\mathrm{b}}$ \\
COM & $5.60 \pm 0.34^{\mathrm{a}}$ & $0.47 \pm 0.01^{\mathrm{b}}$ & $6.60 \pm 0.17^{\mathrm{a}}$ & $4.85 \pm 0.04^{\mathrm{ab}}$ & $70.13 \pm 2.15^{\mathrm{a}}$ & $192.08 \pm 1.17^{\mathrm{a}}$ \\
CHI & $4.05 \pm 0.22^{\mathrm{b}}$ & $0.35 \pm 0.02^{\mathrm{c}}$ & $5.15 \pm 0.14^{\mathrm{b}}$ & $3.00 \pm 0.23^{\mathrm{b}}$ & $66.90 \pm 1.09^{\mathrm{ab}}$ & $163.05 \pm 0.77^{\mathrm{b}}$ \\
\hline
\end{tabular}

MIN - mineral fertiliser; RAB - rabbit manure; COM - compost; CHI - chicken manure; T.N - total Nitrogen; T.P - total Phosphor; T.K - total Potassium; T.Ca - total Calcium; T.Fe - total Iron; T.Zn - total Zinc 
Effect of organic fertilisers on leaf nutrient content

Table 4 presents the effect of fertiliser types on nutrients content $(\mathrm{N}, \mathrm{P}, \mathrm{K}, \mathrm{Ca}, \mathrm{Zn}$, and $\mathrm{Fe})$ in lettuce leaves at the harvest time of 2016 and 2017. Lettuce plants receiving mineral fertiliser and rabbit manure showed higher leaf nutrients content than plots received chicken manure and compost. However, lettuce leaf content of $\mathrm{Fe}$ fertilised by organic fertilisers significantly increased more those fertilised by mineral ones. Over the two seasons, the highest value of leaf $\mathrm{Fe}$ content was observed for plots fertilised by rabbit manure and compost, followed by those of chicken manure and mineral fertilisers.

For 2016, the highest $\mathrm{Zn}$ content in lettuce leaves was recorded for plots fertilised with rabbit manure, followed by compost and chicken manure. For 2017, rabbit manure application showed the highest value of leaf $\mathrm{Zn}$ content, compared to all the other treatments. Thus, insignificant differences in leaf $\mathrm{Zn}$ content were observed for treatments of compost,
A
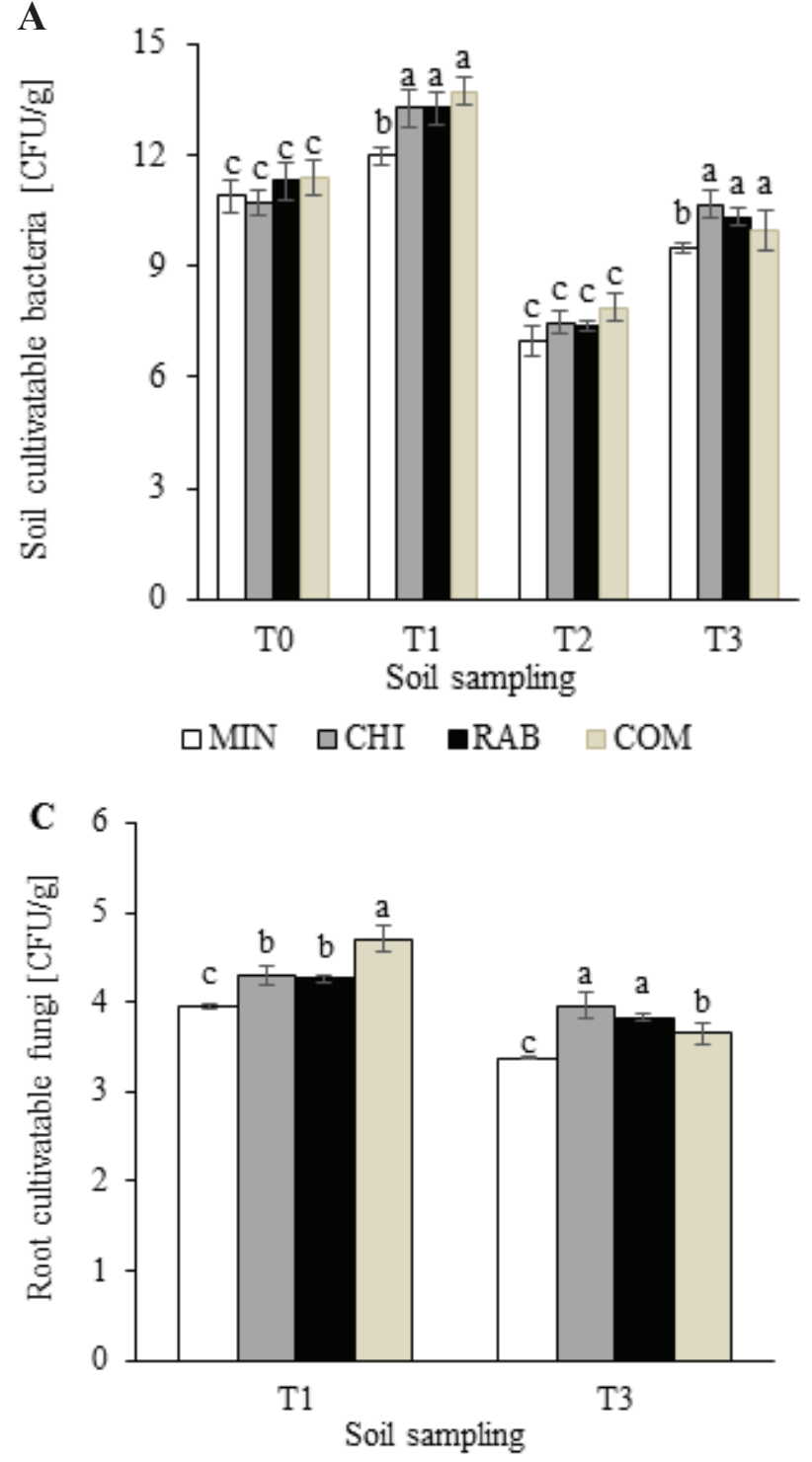

$\square \mathrm{MIN} \square \mathrm{CHI} \square \mathrm{RAB} \square \mathrm{COM}$
B

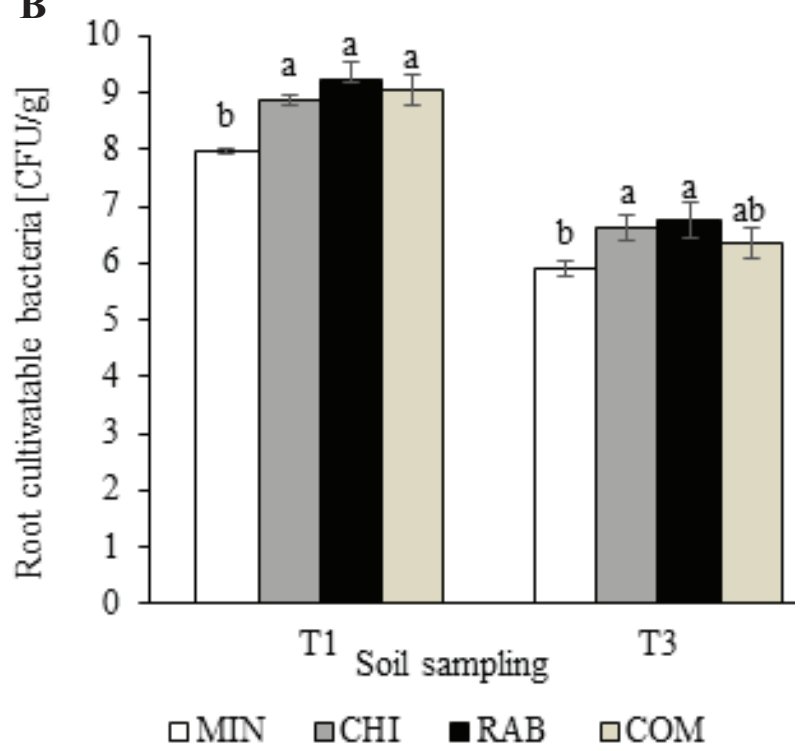

D

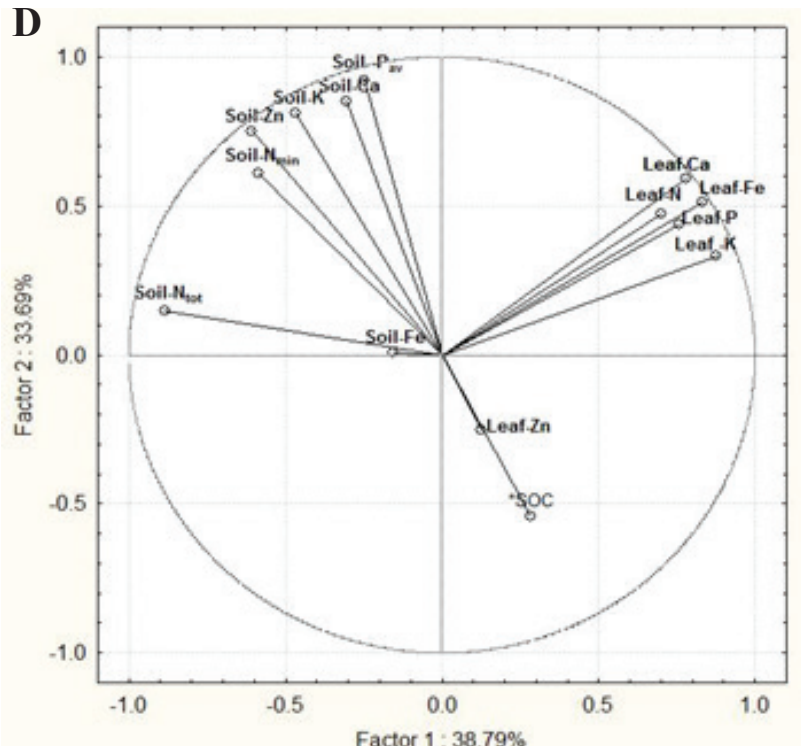

Figure 3. Effect of mineral fertilisers (MIN), chicken manure (CHI), rabbit manure (RAB), and compost (COM). A - soil bacteria and fungi; B - root cultivatable bacteria; C - root cultivatable fungi at different sampling times (T0 \& T2 indicate to initial time, T1 \& T3 indicate to end of trial time). Columns with the same letters are not significantly different according to Tukeytest $(P \leq 0.05)$. Bars are indicating to standard error $(\mathrm{SE})$. D - Principle component analysis (PCA) of leaf nutrient content with soil nutrients content and soil organic carbon (SOC). 
chicken manure, and mineral fertiliser.

The highest leaf contents of N, K, Ca, Zn and Fe recorded for plants treated with rabbit manure might be attributed to the content of the high element of rabbit manure compared with other organic fertilisers (Table 3). Furthermore, the high element's content of rabbit manure had a positive influence on nutrient availability during plant growth (Masunga et al. 2016; Cervera-Mata et al. 2019). However, $\mathrm{P}$ content showed more increase in lettuce leaves fertilised with chicken manure and mineral fertiliser than $\mathrm{P}$ contents in those fertilised with rabbit and compost. No significant difference in the soil available $\mathrm{P}$ content between the applied organic fertilisers (Figure 1F). This can be explained by the high $\mathrm{P}$ uptake of lettuce during the growth cycle and the low $\mathrm{C}$ : $\mathrm{N}$ ratio of chicken manure in the soil. To understand the relationship between leaf nutrient content and soil nutrient content, a PCA has been carried out (Figure 3D). The PCA showed a clear positive relationship between the different available nutrients in the soil and total elements in a lettuce leaf, in particular N, P, K, and Ca. The areas of the leaf and soil nutrient content partially overlapped in the upper quadrants. The area of soil organic carbon was in the lower quadrant. The first component ac-
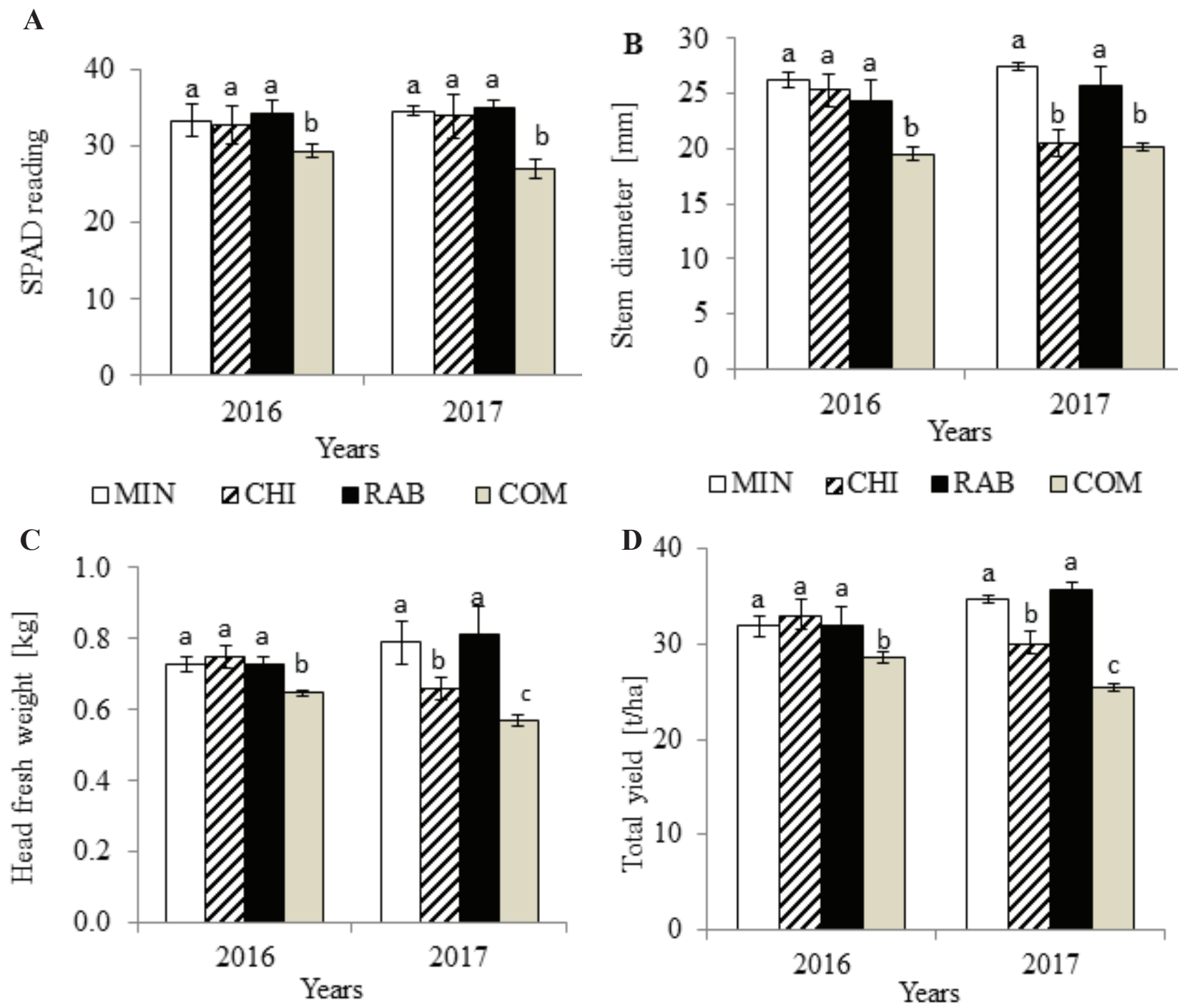

$\square \mathrm{MIN} \quad \square \mathrm{CHI} \quad \mathrm{RAB} \quad \square \mathrm{COM}$

\section{$\square \mathrm{MIN} \quad \square \mathrm{CHI} \quad \mathrm{RAB} \quad \square \mathrm{COM}$}

Figure 4. Effect of mineral fertilisers (MIN), chicken manure (CHI), rabbit manure (RAB), and compost (COM). A - SPAD; $\mathrm{B}$ - stem diameter; $\mathrm{C}$ - head fresh weight; $\mathrm{D}$ - total yield. Columns with the same letters are not significantly different according to Tukeytest $(P \leq 0.05)$. Bars are indicating to standard error $(\mathrm{SE})$. 
counted for a large part of soil macronutrient content, while the second component accounted for those nutrients in the leaves of lettuce plants. Soil macronutrient content, supplied by different organic fertilisers, was caused variation of leaf nutrient content of the treated lettuce plants. Soil organic carbon was found as negatively related to available nutrient accumulation in soil and leaf nutrient contents. Furthermore, a positive relation was found between growth parameter and yield, and nutrient contents $\left(\mathrm{N}_{\text {min }}, \mathrm{P}, \mathrm{K}, \mathrm{Ca}\right.$, and $\mathrm{Zn}$ ) in soil (Figure 4B). A similar correlation was found between SPAD reading (chlorophyll content) and soil - Fe.
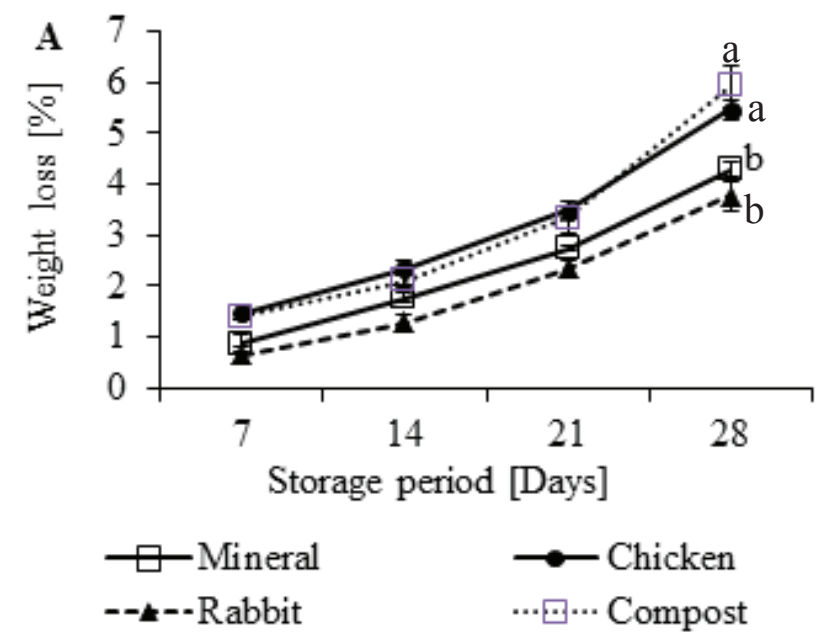

Effect of organic fertilisers on lettuce growth and production

Figure 5 shows the influence of the applied three organic fertilisers on lettuce growth and production parameters in comparison to mineral fertilisers. Compost applications showed the lowest SPAD values over the two growing seasons (Figure 4A). In 2016, there were no significant differences in the stem diameters of lettuce heads. However, compost had resulted in a significantly lower stem diameter (Figure 4B). For 2017, there was no difference in stem diameter resulting from applying mineral fertilisers and rabbit manure or applying chicken ma-

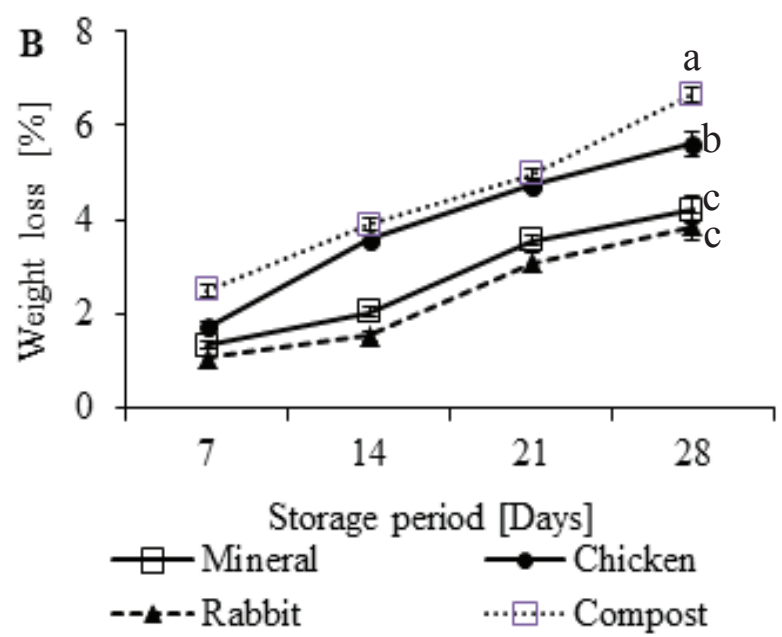

Figure 5. Effect of mineral fertilisers (MIN), chicken manure (CHI), rabbit manure (RAB), and compost (COM) on (A) weight loss in 2016 and (B) weight loss in 2017 of lettuce head stored for 28 days at $2^{\circ} \mathrm{C}$. Points with the same letters are not significantly different according to Tukeytest $(P \leq 0.05)$. Data are mean of $5 \pm \mathrm{SE}$ replicates.

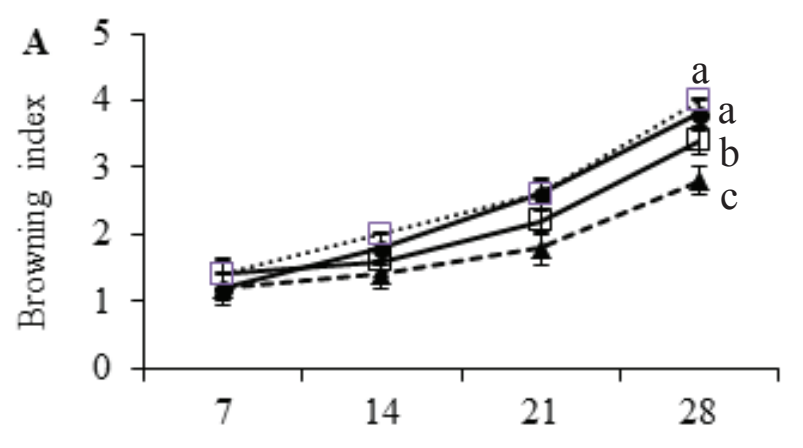

Storage period [Days]
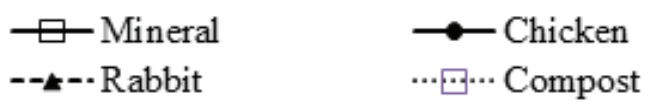

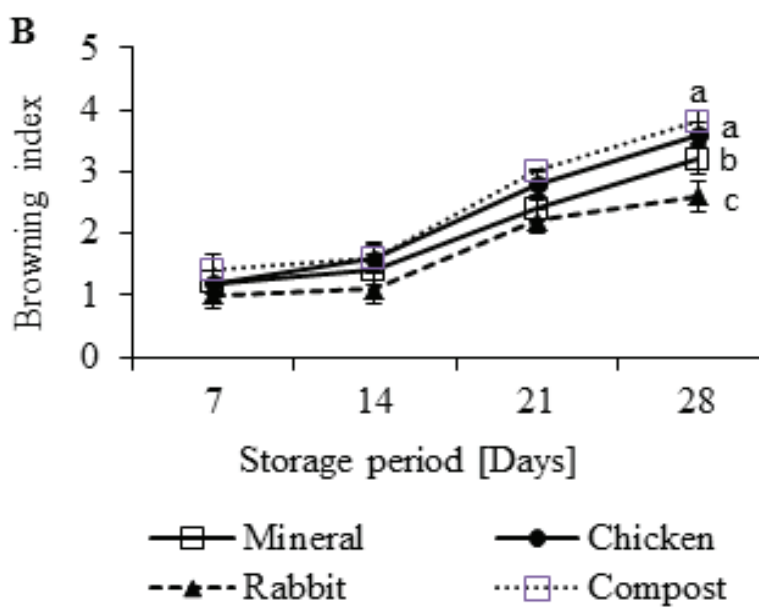

Figure 6. Effect of mineral fertilisers (MIN), chicken manure (CHI), rabbit manure (RAB), and compost (COM). A - browning index $(\mathrm{BI})$ in 2016; $\mathrm{B}$ - browning index in 2017 of lettuce head stored for 28 days at $2^{\circ} \mathrm{C}$. Points with the same letters are not significantly different according to Tukeytest $(P \leq 0.05)$. Data are mean of $5 \pm \mathrm{SE}$ replicates. 
nure and compost. Nonetheless, the stem diameter was significantly higher for treatments of mineral fertilisers and rabbit manure increasing the size of lettuce and, consequently, better quality characteristics. Similar results were noted by Ayoola and Ma- kinde (2014) who observed that the yield of green maize and vegetable cowpea significantly improved with the addition of organic fertilisers.

Figure 4C shows the fresh weight of the lettuce head. In 2016, the fresh weight of lettuce showed

T a b 1 e 5

Effect of mineral fertiliser (MIN), chicken manure (CHI), rabbit manure (RAB), and compost (COM) on the Log number of total bacterial CFU counts of lettuce head stored for 28 days at $2^{\circ} \mathrm{C}$ in 2016 and 2017 . Data are mean of $4 \pm \mathrm{SE}$ replicates. Values within each line followed by the same letter are not significant according to Tukeytest $(P \leq 0.05 \%)$

\begin{tabular}{|c|c|c|c|c|}
\hline \multirow{2}{*}{ Fertiliser } & $0 \mathrm{~d}$ & $7 \mathrm{~d}$ & $14 \mathrm{~d}$ & $21 \mathrm{~d}$ \\
\hline & \multicolumn{4}{|c|}{2016} \\
\hline MIN & $4.20 \pm 0.36^{\mathrm{a}}$ & $5.17 \pm 0.16^{b}$ & $5.42 \pm 0.21^{\mathrm{a}}$ & $6.12 \pm 0.27^{b}$ \\
\hline RAB & $3.85 \pm 0.23^{\mathrm{a}}$ & $5.27 \pm 0.23^{b}$ & $5.52 \pm 0.09^{a}$ & $6.17 \pm 0.37^{b}$ \\
\hline $\mathrm{COM}$ & $3.81 \pm 0.26^{\mathrm{a}}$ & $4.50 \pm 0.26^{c}$ & $5.40 \pm 0.29^{a}$ & $6.02 \pm 0.28^{b}$ \\
\hline $\mathrm{CHI}$ & $3.81 \pm 0.13^{\mathrm{a}}$ & $5.90 \pm 0.13^{\mathrm{a}}$ & $6.26 \pm 0.36^{\mathrm{a}}$ & $6.76 \pm 0.19^{a}$ \\
\hline Fertiliser & \multicolumn{4}{|c|}{2017} \\
\hline MIN & $3.68 \pm 0.32^{b}$ & $4.76 \pm 0.01^{b}$ & $5.36 \pm 0.01^{b}$ & $6.05 \pm 0.42^{b}$ \\
\hline $\mathrm{RAB}$ & $3.29 \pm 0.12^{\mathrm{c}}$ & $4.49 \pm 0.02^{c}$ & $5.33 \pm 0.01^{\mathrm{b}}$ & $5.82 \pm 0.19^{b}$ \\
\hline $\mathrm{COM}$ & $3.87 \pm 0.05^{\mathrm{a}}$ & $4.43 \pm 0.02^{c}$ & $5.20 \pm 0.01^{\mathrm{c}}$ & $5.47 \pm 0.10^{c}$ \\
\hline $\mathrm{CHI}$ & $3.80 \pm 0.08^{a}$ & $5.87 \pm 0.04^{\mathrm{a}}$ & $5.53 \pm 0.04^{\mathrm{a}}$ & $6.53 \pm 0.04^{\mathrm{a}}$ \\
\hline
\end{tabular}

$\mathrm{MIN}$ - mineral fertiliser; RAB - rabbit manure; COM - compost; $\mathrm{CHI}$ - chicken manure

T a b 1 e 6

Effect of mineral fertiliser (MIN), chicken manure (CHI), rabbit manure (RAB), and compost (COM) on the Log number of total fungal CFU counts of lettuce head stored for 28 days at $2^{\circ} \mathrm{C}$ in 2016 and 2017 . Data are mean of $4 \pm \mathrm{SE}$ replicates. Values within each line followed by the same letter are not significant according to Tukeytest $(P \leq 0.05 \%)$.

\begin{tabular}{|c|c|c|c|c|}
\hline \multirow{2}{*}{ Fertiliser } & $0 \mathrm{~d}$ & $7 \mathrm{~d}$ & $14 \mathrm{~d}$ & $21 \mathrm{~d}$ \\
\hline & \multicolumn{4}{|c|}{2016} \\
\hline MIN & $2.17 \pm 0.20^{b}$ & $2.33 \pm 0.15^{b}$ & $3.10 \pm 0.40^{\mathrm{a}}$ & $3.18 \pm 0.34^{\mathrm{a}}$ \\
\hline RAB & $1.90 \pm 0.00^{\mathrm{b}}$ & $2.33 \pm 0.15^{b}$ & $2.90 \pm 0.19^{\mathrm{a}}$ & $3.01 \pm 0.15^{\mathrm{a}}$ \\
\hline $\mathrm{COM}$ & $2.58 \pm 0.78^{\mathrm{a}}$ & $3.02 \pm 0.66^{\mathrm{a}}$ & $3.00 \pm 0.90^{\mathrm{a}}$ & $3.14 \pm 0.08^{a}$ \\
\hline $\mathrm{CHI}$ & $2.91 \pm 0.41^{\mathrm{a}}$ & $2.84 \pm 0.16^{\mathrm{a}}$ & $2.98 \pm 0.50^{\mathrm{a}}$ & $3.01 \pm 0.18^{\mathrm{a}}$ \\
\hline Fertiliser & \multicolumn{4}{|c|}{2017} \\
\hline MIN & $2.05 \pm 0.21^{\mathrm{d}}$ & $2.55 \pm 0.07^{b}$ & $3.20 \pm 0.13^{\mathrm{a}}$ & $3.07 \pm 0.10^{b}$ \\
\hline RAB & $2.34 \pm 0.06^{\mathrm{c}}$ & $2.64 \pm 0.06^{b}$ & $2.50 \pm 0.11^{\mathrm{b}}$ & $2.64 \pm 0.09^{c}$ \\
\hline $\mathrm{COM}$ & $2.59 \pm 0.12^{b}$ & $2.75 \pm 0.04^{\mathrm{a}}$ & $3.10 \pm 0.08^{\mathrm{a}}$ & $3.09 \pm 0.04^{b}$ \\
\hline $\mathrm{CHI}$ & $2.68 \pm 0.09^{\mathrm{a}}$ & $2.80 \pm 0.04^{\mathrm{a}}$ & $3.21 \pm 0.08^{\mathrm{a}}$ & $3.40 \pm 0.06^{\mathrm{a}}$ \\
\hline
\end{tabular}

MIN - mineral fertiliser; RAB - rabbit manure; COM - compost; $\mathrm{CHI}$ - chicken manure 
insignificant differences in the case of treatments of mineral fertilisers, rabbit, and chicken manure. Compost treatment, however, showed significantly lower weights. This result could be due to the lower concentration of $\mathrm{N}$ in compost. In 2017, the highest values of lettuce head fresh weight were recorded for mineral fertilisers and rabbit manure followed by chicken manure and compost (Figure 4C). Lettuce production showed a similar pattern over 2016 and 2017 for each fertiliser used (Figure 4D). The better growth and higher production of lettuce that observed for rabbit and chicken manure treatment could be explained by the regular mineralization of organic matter by which nutrients were available at any plant time of need (Angin et al. 2017). Similar results were reported by Muymas et al. (2015) who observed that lettuce fresh weight, dry weight, leaf number, width, and length had increased by applying chitin-rich residues. The less effect of compost on fresh weight of lettuce head and SPAD reading in this study might be due to its lower content of nutrients, as reported by Murakami et al. (2011) and Mahmoud et al. (2020).

Effect of organic fertilisers on weight loss of head lettuce during storage

The quality of lettuce head during refrigerated storage at $2^{\circ} \mathrm{C}$ for 28 days was affected by organic
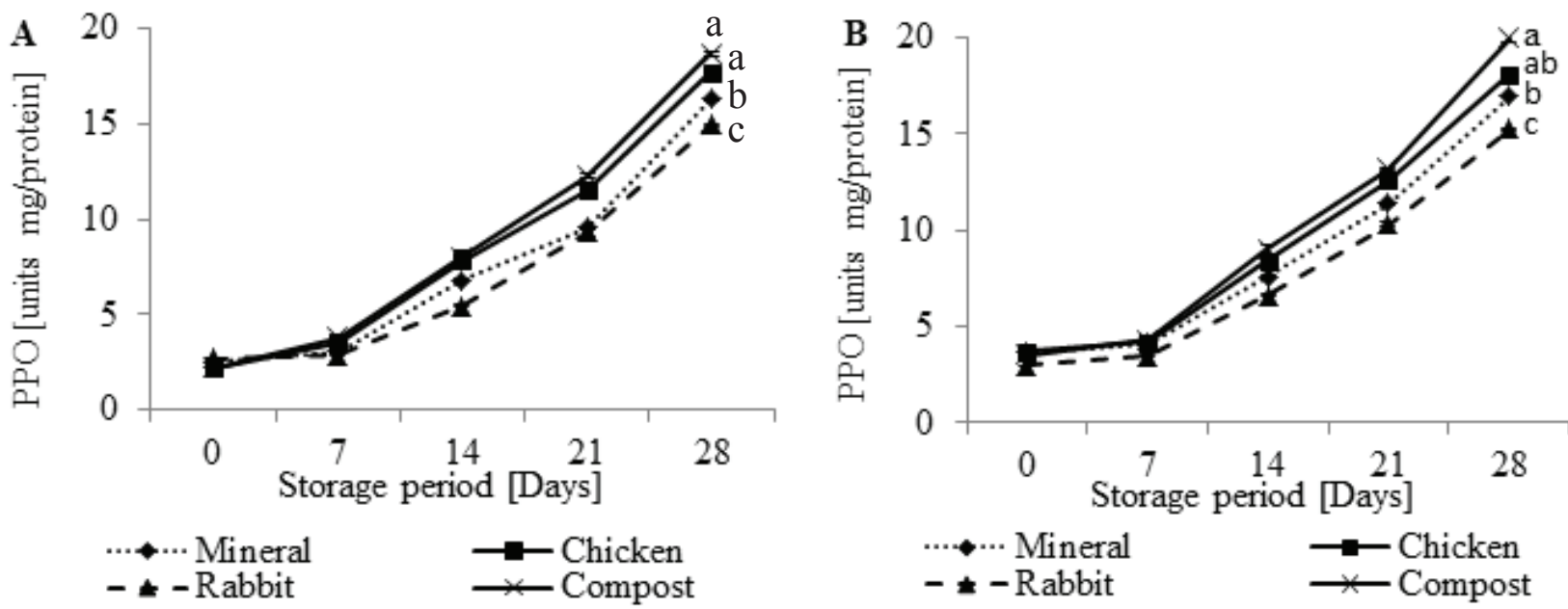

Figure 7. Effect of mineral fertilisers (MIN), chicken manure (CHI), rabbit manure (RAB), and compost (COM). A - polyphenol oxidase (PPO) in 2016; B - polyphenol oxidase in 2017 of lettuce head stored for 28 days at $2^{\circ} \mathrm{C}$. Points with the same letters are not significantly different according to Tukeytest $(P \leq 0.05)$. Data are mean of 5 replicates.
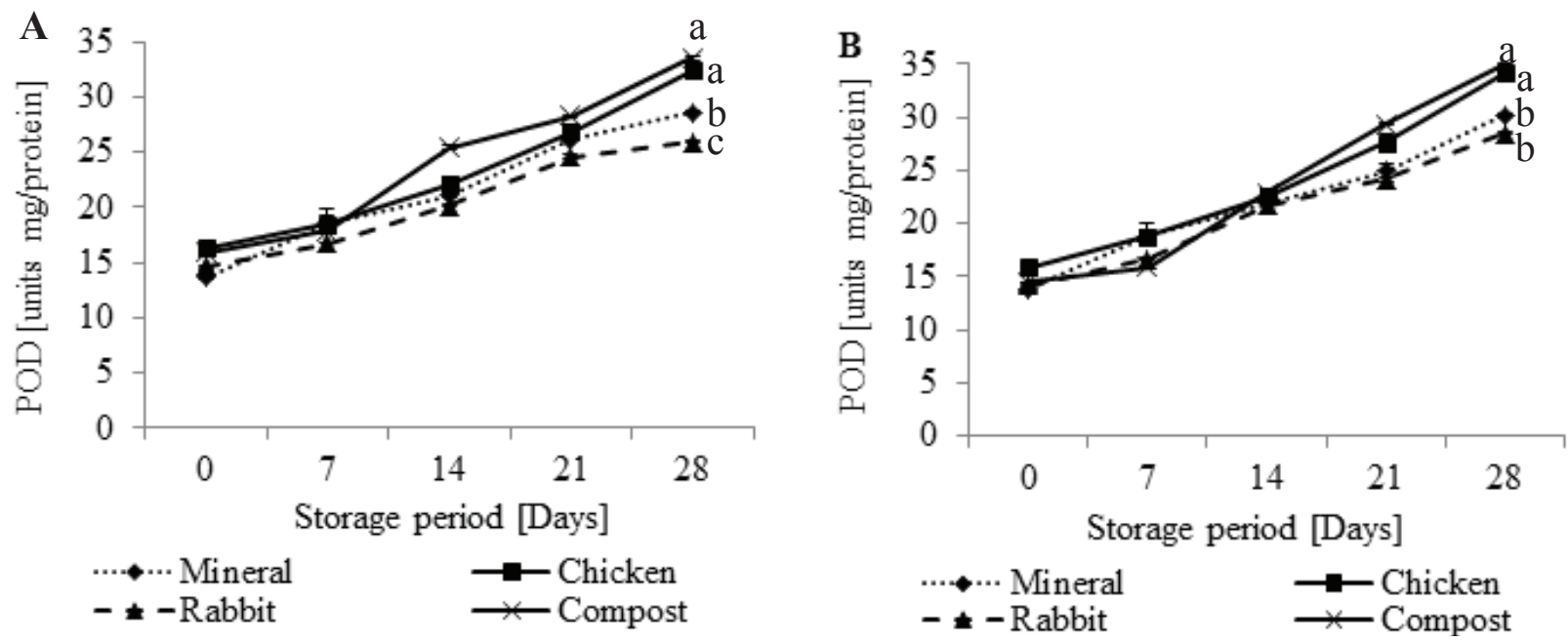

Figure 8. Effect of mineral fertilisers (MIN), chicken manure (CHI), rabbit manure (RAB), and compost (COM). A - peroxidase activity (POD) in 2016; B - peroxidase activity in 2017 of lettuce head stored for 28 days at $2^{\circ} \mathrm{C}$. Points with the same letters are not significantly different according to Tukeytest $(P \leq 0.05)$. Data are mean of 5 replicates. 
and inorganic fertiliser applications. The weight loss of stored lettuce head increased with increasing storage duration (Figure 5A and B). Increasing weight loss during storage could be due to the increase of respiration and transpiration during storage (El-Mogy et al. 2019c). The weight loss of lettuce fertilised with chicken and compost was higher than lettuce fertilised with rabbit manure and mineral fertiliser over the two seasons. This reduction in weight loss may be due to the increase of dry matter in lettuce heads by organic fertilisers (El-Sayed et al. 2015).

There was a negative correlation $(r=0.90)$ between weight loss and leaf calcium content. The positive effects of calcium in reducing weight loss of lettuce heads fertilised with organic sources could be due to its importance in maintaining cell wall structure and firmness (El-Mogy et al. 2019d).

Effect of organic fertilisers on the browning index and enzymatic browning during storage

Enzymatic browning is considering one of the most important factors affecting the shelf-life of some vegetables (EL-Mogy et al. 2020). Data in Figure 6 (A and $\mathrm{B}$ ) showed the browning colour of the lettuce surface during storage. Browning colour was increased with increasing storage period. There were no significant differences between treatments after 7 and 14 days of storage. After 21 and 28 days, the lowest browning index was recorded for rabbit manure followed by mineral fertiliser. Chicken manure and compost treatments had the highest browning indexes. Similar tendencies were, also, noted with the activity of polyphenol oxidase (PPO) and peroxidase enzymes (POD) (Figure 7,8) where the activity of those enzymes increased gradually with storage periods (Shehata et al. 2020).

The minimum activity of PPO and POD in lettuce leaves was observed in plants treated with rabbit manure followed by chemical fertiliser and chicken manure. The highest activities of both enzymes were observed in plants fertilised by compost (Degl'Innocenti et al. 2005; Santos et al. 2016). This might be due to the increment of endogenous nutrients concentrations, particularly the $\mathrm{Ca}$ element. Moreover, the results of PCA and simple regression reflected a strong positive relation between browning index (BI) and polyphenol oxidase (PPO) accumulation in leaves $\left(R^{2}=0.98\right.$, Figure 9). However, BI correlated negatively with $\mathrm{Ca}$ accumulation in leaves $\left(R^{2}=0.90\right)$. Furthermore, the PCA indicated that PPO and POD enzymes were positively correlated to browning. Thus, the increment of endogenous Ca content in plant tissue can reduce the browning appearance (Figure 9A). Khumjing et al. (2011) found that $\mathrm{Ca}$, in the form of $\mathrm{CaCl}_{2}$, when applied to the soil, significantly reduced the activity of PPO as well as phenolic and
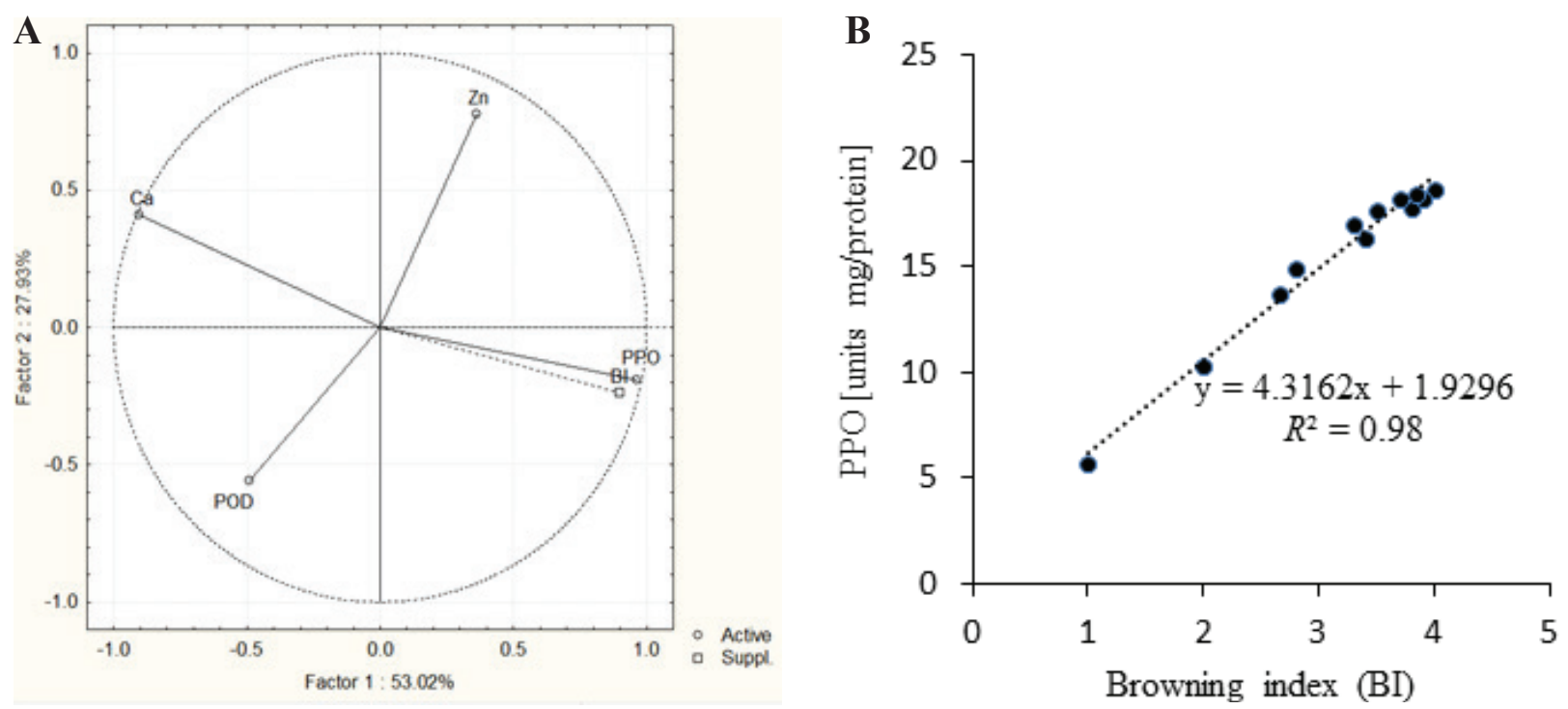

Figure 9. Principle component analysis of leaf calcium content. A - with polyphenol oxidase (PPO); browing index (BI) and proxidase (POD) additionally simple regresion study. B - between polyphenol oxidase (PPO), browing index (BI). 
quinone in Grand Rapids lettuce. Also, Ca played a positive role in the reduction of the activity of POD in plant tissue and, consequently, reduced the browning (Rico et al. 2006; Luna et al. 2012) in lettuce. Other studies reported that $\mathrm{Ca}$ preserved cell membrane integrity and reduced the activity of PPO which delayed the browning occurrence (e.g. Brummell et al. 2004).

\section{Effect of organic fertilisers on microbiological analysis of lettuce head}

Total bacterial and fungal counts during storage of lettuce head were presented in Table 5 and 6 . Total bacterial and fungal spoilages on lettuce surfaces increased with increasing the period of storage. The highest bacterial population was recorded in lettuce leaves grown under chicken manure compared to all other treatments. By contrast, the lowest population of bacteria was observed in lettuce plants fertilised by compost at the end of storage during 2017 (Table 5). Similarly, the enumeration of total fungal counts showed the highest population for lettuce plants fertilised by compost and chicken manure during 2017. However, lettuce plants, amended by chemical fertilisers or rabbit manure treatments, significantly reduced the microbial growth on lettuce surfaces during storage times (Table 6). This reduction could be related to the initial account of microbes on lettuce before storage as reported by Bolin et al. (1977). Additionally, the inhibitory effect of endoge nous $\mathrm{Ca}$ might be a result of increased resistance of tissue to bacterial attack rather than to a bactericidal action. Conway and Sams (1984) reported that $\mathrm{Ca}$ increased tissue resistance to fungal infection through stabilizing or strengthening cell walls in, a way resisting pectolytic enzymes released by fungi.

\section{CONCLUSIONS}

This study indicated that organic fertiliser positively affects soil microbial community and fertility. Lettuce plants can be fertilised with rabbit manure at $10 \mathrm{t} / \mathrm{h}$ without affecting yield and this rate leads to improvement in head quality. Furthermore, the use of rabbit manure reduced weight loss, microbial load, and enzymatic browning during refrigerated storage at $2^{\circ} \mathrm{C}$. Compared with conventional fertilis- er, organic fertiliser, especially with rabbit manure, could be an effective way to reduce the harmful effect of mineral fertiliser on the environment and human health.

\section{Declarations}

Funding: Cairo University, Giza, Egypt

Conflicts of interest: There are no conflicts of interest.

\section{REFERENCES}

ABBASI, M.K. - TAHIR, M.M. - SABIR, N. - KHURSHID, M. 2015. Impact of the addition of different plant residues on nitrogen mineralization-immobilization turnover and carbon content of a soil incubated under laboratory conditions. In Solid Earth, vol. 6, pp. 197-205. DOI: 10.5194/ se-6-197-2015.

ABDELDAYM, E.A. - ERRIQUENS, F. - VERRASTRO, V. - SASANELLI, N.- MONDELLI, D. - COCOZZA, C. 2012. Nematicidal and fertilizing effects of chicken manure, fresh and composted olive mill wastes on organic melon. In Helminthologia, vol. 49, no. 4, pp. 259-269. DOI: $10.2478 / \mathrm{s} 11687-012-0048-4$.

ABDELDAYM, E.A. - EL-SAWY, M.B.I. - EL-HELALY, M.A. 2019. Combined application of different sources of nitrogen fertilizers for improvement of potato yield and quality. In Plant Archives, vol. 19, 2513.

ABDELDAYM, E.A. - ERRIQUENS, F. - SASANELLI, N. CEGLIE, F.G. - ZACCONE, C. - MIANO, T. - COCOZZ, C. 2014. Effects of several amendments on organic melon growth and production, Meloidogyne incognita population and soil properties. In Scientia Horticulturae, vol. 180, pp. 156-160. DOI: 10.1016/j.scienta.2014.10.032.

ABDELDAYM, E.A. - TRAVERSA, A. - COCOZZA, C. BRUNETTI, G. 2018. Effects of a 2-year application of different residual biomasses on soil properties and potato yield. In Clean Soil Air Water, vol. 46, no. 12, 1800261. DOI: 10.1002/clen.201800261.

ABUARAB, M.E. - EL-MOGY, M.M. - HASSAN, A.M. ABDELDAYM, E.A. - ABDELKADER, N.H. - BI ELSAWY, M. 2019. The effects of root aeration and different soil conditioners on the nutritional values, yield, and water productivity of potato in clay loam soil. In Agronomy, vol. 9, no. 8, 418. DOI: 10.3390/agronomy9080418.

ADANDE, R. - BOKOSSA, H.K. J. - LIADY, M. - FIOGBÉ, E.D. 2017. Valorization of various sources of rabbit manure in agro-piscicultural system in Benin (West Africa): dynamics and effect of mineralization upon quality of fresh water. In International Journal of Recycling of Organic Waste in Agriculture, vol. 6, no. 3, pp. 233-243.

ADENIYAN, O.N. - OJENIYI, S.O. 2005. Effect of poultry manure, NPK 15-15-15 and combination of their reduced levels on maize growth and soil chemical properties. In $\mathrm{Ni}$ gerian Journal of Soil Science, vol. 15, no. 1, pp. 34-34.

ALAM, M. - AHLSTRÖM, C. - BURLEIGH, S. - OLSSON, C. - AHRNÉ, S. - EL-MOGY, M. - MOLIN, G. - JENSÉN, P. - HULTBERG, M. - ALSANIUS, B.W. 2014. Prevalence of Escherichia coli O157: H7 on spinach 
and rocket as affected by inoculum and time to harvest. In Scientia Horticulturae, vol. 165, pp. 235-241. DOI 10.1016/j.scienta.2013.10.043.

AMALRAJ, E.L.D. - KUMAR, G.P. - AHMED, S.K.M.H. ABDUL, R. - KISHORE, N. 2013. Microbiological analysis of Panchagavya, vermicompost, and FYM and their effect on plant growth promotion of pigeon pea (Cajanus cajan L.) in India. In Organic Agriculture, vol. 3, pp. 23-29. DOI: $10.1007 / \mathrm{s} 13165-013-0042-2$.

ANGERS, D.A. - ARROUAYS, D. - SABY, N.P.A. - WALTER, C. 2011. Estimating and mapping the carbon saturation deficit of French agricultural topsoils. In Soil Use and Management, vol. 27, pp. 448-452. DOI: 10.1111/j.14752743.2011.00366.x.

ANGIN, I. - ASLANTAS, R. - GUNES, A. - KOSE, M. OZKAN, G. 2017. Effects of Sewage sludge amendment on some soil properties, growth, yield and nutrient content of raspberry (Rubus idaeus L.). In Erwerbs Obstbau, vol 59, pp. 93-99. DOI: 10.1007/s10341-016-0303-9.

APESTEGUIAA, M. - PLANTE, A.F. - VIRTOC, I. 2018. Methods assessment for organic and inorganic carbon quantification in calcareous soils of the Mediterranean region. In Geoderma Regional, vol. 12, pp. 39-48. DOI: 10.1016/j.geodrs.2017.12.001.

ASSES, N. - FARHAT, A. - CHERIF, S. - HAMDI, M. BOUALLAGUIA, H. 2018. Comparative study of sewage sludge co-composting with olive mill wastes or green residues: Process monitoring and agriculture value of the resulting composts. In Process Safety and Environmental Protection, vol. 114, pp. 25-35. DOI: 10.1016/j. psep.2017.12.006.

Association of Official Analytical Chemists - AOAC 1990. Official Methods of Analysis, 15th Edn. AOAC, Washington, D.C, pp. 556.

ATIA, M.A - ABDELDAYM, E.A. - ABDELSATTAR, M. IBRAHIM, D.S. - SALEH, I. - ABD ELWAHAB, M. OSMAN, G.H. - ARIF, I.A. - ABDELAZIZ, M.E. 2020. Piriformospora indica promotes cucumber tolerance against Root-knot nematode by modulating photosynthesis and innate responsive genes. In Saudi Journal of Biological Sciences, vol. 27, no. 1, pp. 279-287. DOI: 10.1016/j. sjbs.2019.09.007.

AYOOLA, O.T. - MAKINDE, E.A. 2014. Soil nutrient dynamics, growth and yield of green maize and vegetable cowpea with organic-based fertilization. In Archives of Agronomy and Soil Science, vol. 60, no. 2, pp. 183-194. DOI: $10.1080 / 03650340.2013 .775422$

AYYOBI, H. - OLFATI, J.A. - PEYVAST, G.A. 2014. The effects of cow manure vermicompost and municipal solid waste compost on peppermint (Mentha piperita L.) in Torbat-e-Jam and Rasht regions of Iran. In International Journal of Recycling of Organic Waste in Agriculture, vol. 3, pp. 147-153. DOI: 10.1007/s40093-014-0077-8.

AZEEZ, J.O. - VAN-AVERBEKE, W. 2012. Dynamics of soil $\mathrm{pH}$ and electrical conductivity with the application of three animal manures. In Communications in Soil Science and Plant Analysis, vol. 43, no. 6, pp. 865-574. DOI: 10.1080/00103624.2012.653022.

BESTWICK, C.S. - BROWN, I.R. - MANSFIELD, J.W 1998. Localized changes in peroxidase activity accompany hydrogen peroxide generation during the development of a non-host hypersensitive reaction in lettuce. In Plant Physiology, vol. 118, no. 3, pp. 1067-1078. DOI: 10.1104/ pp.118.3.1067.

BOLIN, H.R. - STANFFORD, A.D. - KTNG, J.R. - HUXSOLL, C.C. 1977. Factors affecting the storage stabili- ty of shredded lettuce. In Journal of Food Science, vol. 42, no. 5, 1319-1321. DOI: 10.1111/j.1365-2621.1977. tb14487.x.

BIRATU, G.K. - ELIAS, E. - NTAWURUHUNGA, P. 2019. Soil fertility status of cassava fields treated by integrated application of manure and NPK fertilizer in Zambia. In Environmental System Research, vol. 8, article number 3. DOI: 10.1186/s40068-019-0131-7.

BRUMMELL, D.A. - DAL CIN, V. - CRISOSTO, C.H. - LABAVITCH, J.M. 2004. Cell wall metabolism during maturation, ripening and senescence of peach fruit. In Journal of Experimental Botany, vol. 55, no. 405, pp. 2029-2039. DOI: $10.1093 / \mathrm{j} x \mathrm{~b} / \mathrm{erh} 227$.

BURGER, M. - VENTEREA, R.T. 2008. Nitrogen immobilization and mineralization kinetics of cattle, hog and turkey manure applied to soil. In Soil Science Society of America Journal, vol. 72, no. 6, pp. $1570-1579$. DOI: $10.2136 /$ sssaj2007.0118.

CAMPITELLI, P. -VELASCO, M. - CEPPI, S. 2012.Characterization of humic acids derived from rabbit manure treated by composting-vermicomposting process. In Journal of Soil Science and Plant Nutrition, vol. 12, no. 4, pp. 875-891. DOI: 10.4067/S0718-95162012005000039.

CAO, S. - ZHENG, Y. - WANG, K. - JIN, P. - RUI, H. 2009. Methyl jasmonate reduces chilling injury and enhances antioxidant enzyme activity in postharvest loquat fruit. In Food Chemistry, vol. 115 , no. 4, pp. 1458-1463. DOI: 10.1016/j.foodchem.2009.01.082.

CERVERA-MATA, A. - NAVARRO-ALARCÓN, M. - DELGADO, G. - PASTORIZA, S. - MONTILLA-GÓMEZ, J. - LLOPIS, J. - SÁNCHEZ-GONZÁLEZ, C. - RUFIÁN-HENARES, J.Á. 2019. Spent coffee grounds improve the nutritional value in elements of lettuce (Lactuca sativa $\mathrm{L}$.) and are an ecological alternative to inorganic fertilizers. In Food Chemistry, vol. 282, pp. 1-8. DOI: 10.1016/j.foodchem.2018.12.101

CERVERA-MATA, A. - PASTORIZA, S. - RUFIÁN-HENARES, J.Á. - PÁRRAGA, J. - MARTÍN-GARCÍA, J.M. - DELGADO, G. 2018. Impact of spent coffee grounds as organic amendment on soil fertility and lettuce growth in two Mediterranean agricultural soils. In Archives of Agronomy and Soil Sciences, vol. 64, no. 6, pp. 790-804. DOI: 10.1080/03650340.2017.1387651.

CHAKRABORTY, A. - CHAKRABARTI, K. CHAKRABORTY, A. - GHOSH, S. 2012. Effect of longterm fertilizers and manure application on microbial biomass and microbial activity of a tropical agricultural soil. In Biology and Fertility of Soils, vol. 47, pp. 227-233. DOI: 10.1007/s00374-010-0509-1.

CHATTERJEE, R. - BANDYOPADHYAY, S. - JANA, J.C. 2014. Evaluation of vegetable wastes recycled for vermicomposting and its response on yield and quality of carrot (Daucus carota L.). In International Journal of Recycling of Organic Waste in Agriculture, vol. 3, no. 60, pp. 1-7. DOI: 10.1007/s40093-014-0060-4.

CHEN, Y.M. - XU, X. - JIAO, X.G. - SUI, Y.Y. - LIU, X.B. - ZHANG, J.Y. - ZHOU, K. - ZHANG, J.M. 2018. Responses of labile organic nitrogen fractions and enzyme activities in eroded Mollisols after 8-year manure amendment. In Scientific Reports UK, vol. 8, 14179. DOI: 10.1038/s41598-018-32649-y.

CHERNEY, J.H. - MIKHAILOWA, E.A. - CHERNEY, D.J.R. 2002. Tetany potential of orchardgrass and tall fescue as influenced by fertilization with dairy manure or commercial fertilizer. In Journal of Plant Nutrition, vol. 25, pp. 1501-1525. DOI: 10.1081/PLN-120005405.

CIAVATTA, C. - ANTISARI, L.V. - SEQUI, P. 1989. Deter- 
mination of organic carbon in soils and fertilizers. In Communication in Soil Science and Plant Analysis, vol. 20, pp. 759-773. DOI: 10.1080/00103628909368115.

CONWAY, W.S. - SAMS, C.E. 1984. Possible mechanism by which postharvest calcium treatment reduces decay in apples. In Phytopathology, vol. 74, no. 2, pp. 208-210.

DEGL'INNOCENTI, E. - GUIDI, L. - PARDOSSI, A. - TOGNONI, F. 2005. Biochemical study of leaf browning in minimally processed leaves of lettuce (Lactuca sativa L. var. Acephala). In Journal of Agricultural and Food Chemistry, vol. 53, pp. 9980-9984.

DELLAVALLE, N.B. 1992. Determination of specific conductance in supernatant 1:2 soil: water solution. In DELLAVALLEM, N.B. (Ed.), Handbook on Reference Methods for Soil Analysis. Soil and Plant Analysis Council. Inc.: Athens, GA., pp. 44-50.

EC. Regulation (EC) N. 1257/2014 the European Parliament and of the Council relating to fertilisers for the purposes of adapting Annexes I and IV Text with EEA relevance. 2014.

EC. Regulation (EC) N. 1107/2009 of the European Parliament and of the Council of the European Parliament of 21 October 2009 concerning the placing of plant protection products on the market and repealing Council Directives 79/117/EEC and 91/414/EEC. Off. J. Legis. 309.

EL-MOGY, M.M. - ALI, M.R. - DARWISH, O.S. - ROGERS, S.J. 2019c. Impact of salicylic acid, abscisic acid, and methyl jasmonate on postharvest quality and bioactive compounds of cultivated strawberry fruit. In Journal of Berry Research, vol. 9, pp. 333-348.

EL-MOGY, M.M. - GARCHERY, C. - STEVENS, R. 2018. Irrigation with salt water affects growth, yield, fruit quality, storability and marker-gene expression in cherry tomato. In Acta Agriculturae Scandinavica, Section B Soil \& Plant Science, vol. 68, no. 8, pp. 727-737. DOI: 10.1080/09064710.2018.1473482.

EL-MOGY, M.M. - LUDLOW R.A. - ROBERTS, C. MÚLLER, C.T. - ROGERS, H.J. 2019a. Postharvest exogenous melatonin treatment of strawberry reduces postharvest spoilage but affects components of the aroma profile. In Journal of Berry Research, vol. 9, pp. 297-307.

EL-MOGY, M.M. - MAHMOUD, A.W.M. - EL-SAWY, M.B.I. - PARMER, A. 2019d. Pre-harvest foliar application of mineral nutrients to retard chlorophyll degradation and preserve bio-active compounds in broccoli. In Agronomy, vol. 9, 711.

EL-MOGY, M.M. - PARMER, A. - ALI, M.R. ABDEL-AZIZ, M.E. - ABDELDAYM, E.A. 2020. Improving postharvest storage of fresh artichoke bottoms by an edible coating of Cordia myxa gum. In Postharvest Biology and Technology, vol. 163, 111143 .

EL-MOGY, M.M. - SALAMA, A.M. - MOHAMED, H.F. ABDELGAWAD, K.F. - ABDELDAYM, E.A. 2019b. Responding of long green pepper plants to different sources of foliar potassium fertilizer. In Agriculture (Polnohospodárstvo), vol. 65 , no. 2 , pp. 59-76. DOI: $10.2478 /$ agri2019-0007

El-SAYED, F.S. - HASSAN, H.A. - EL-MOGY, M.M. 2015. Impact of bio and organic fertilizers on potato yield, quality and tuber weight loss after harvest. In Potato Research, vol. 58 , pp. $67-81$.

FAOSTAT. 2015. http://www.fao.org/faostat/en/\#data/QC.

FEDERICIA, E. - MASSACCESI, L. - PEZZOLLAC, D. FIDATIA, L. - MONTALBANIA, E. - PROIETTIB, P. - NASINIB, L. - REGNI, L. - SCARGETTA, S. - GIGLIOTTIC, G. 2017. Short-term modifications of soil microbial community structure and soluble organic matter chemical composition following amendment with different solid olive mill waste and their derived composts. In $\mathrm{Ap}$ plied Soil Ecology, vol. 119, pp. 234-241. DOI: 10.1016/j. apsoil.2017.06.014.

FERNÁNDEZ-HERNÁNDEZ, A. - ROIG, A. - SERRAMIÁ, N. - CIVANTOS, G.C. - SÁNCHEZ-MONEDERO, M.A. 2014. Application of compost of two-phase olive mill waste on olive grove: Effects on soil, olive fruit and olive oil quality. In Waste Managent, vol. 34, no. 7, pp. 1139-114. DOI: 10.1016/j.wasman.2014.03.027.

HERNÁNDEZ, T. - CHOCANO, C. - MORENO, J.L. GARCÍA, C. 2014. Towards a more sustainable fertilization: combined use of compost and inorganic fertilization for tomato cultivation. In Agriculture, Ecosystem \& Environment, vol. 196, pp. $178-184$. DOI: $10.1016 / j$. agee.2014.07.006.

HERNÁNDEZ, T. - CHOCANO, C. - MORENO, J.L. GARCÍA, C. 2016. Use of compost as an alternative to conventional inorganic fertilizers in intensive lettuce ( $\mathrm{Lac}$ tuca sativa L.) crops-effects on soil and plant. In Soil and Tillage Research, vol. 160, pp. 14-22. DOI: 10.1016/j. still.2016.02.005.

INDORANTE, S.J. - FOLLMER, L.R. - HAMMER, R.D. - KOENIG, P.G. 1990. Particle-size analysis by a modified pipette procedure. In Soil Science Society of America Journal, vol. 54, no. 2, pp. 560-563. DOI: $10.2136 /$ sssaj1990.03615995005400020047x.

JACKSON, M.L. 1973. Soil Chemical Analysis. Second Edition. Prentice Hall India Pvt Ltd.: New Delhi, India. 498 p.

KHALIL, H.A. - HASSAN, S.M. 2015. Ascorbic acid, carotene, total phenolic compound and microbiological quality of organic and conventional citrus and strawberry grown in Egypt. In African Journal of Biotechnology, vol. 14, no. 4, pp. $272-277$. DOI: 10.5897/AJB2014.14170.

KHUMJING, C. - CHUTICHUDET, B. - CHUTICHUDET, P. - BOONTIANG, K. 2011. Effects of different calcium applications for controlling browning appearance in lettuce. In International Journal of Agricultural Research, vol. 6, no. 3, pp. 238-253. DOI: 10.3923/ijar.2011.238.254.

LIANG, B. - ZHAO, W. - YANG, X. - ZHOU, J. 2013. Fate of nitrogen-15 as influenced by soil and nutrient management history in a 19-year wheat-maize experiment. In Field Crop Research, vol. 144, pp. 126-134. DOI: 10.1016/j. fcr.2012.12.007.

LIU, E. - YAN, C. - MEI, X. - HE, W. - BING, S.H., ET AL. 2010. Long-term effect of chemical fertilizer, straw, and manure on soil chemical and biological properties in northwest China. In Geoderma, vol. 158, no. 3-4, pp. 173 -180. DOI: 10.1016/j.geoderma.2010.04.029.

LUNA, C. - TUDELA, J.A. - MARTNEZ-SNCHEZ, A. - ALLENDE, A. - MARN, A. - GIL, M.I. 2012. Long term deficit and excess of irrigation influences quality and browning related enzymes and phenolic metabolism of fresh-cut iceberg lettuce (Lactuca sativa L.). In Postharvest Biology and Technology, vol. 73, pp. 37-45. DOI: 10.1016/j.postharvbio.2012.05.011.

MAHMOUD, A.W.M. - ABDELDAYM, E.A. - ABDELAZIZ, S.M. - EL-SAWY, M.B. - MOTTALEB, S.A. 2020. Synergetic effects of zinc, boron, silicon, and zeolite nanoparticles on confer tolerance in potato plants subjected to salinity. In Agronomy, vol. 10, no. 1, 19. DOI: 10.3390/agronomy10010019.

MAHMOUD, A.W.M. - ABDELAZIZ, S. - EL-MOGY, M.M. -ABDELDAYM, E.A. 2019. Effect of foliar $\mathrm{ZnO}$ and $\mathrm{FeO}$ nanoparticles application on growth and nutritional quality of red radish and assessment of their accumulation on hu- 
man health. In Agriculture (Pol'nohospodárstvo), vol. 65, no.1, pp. 16-29. DOI: 10.2478/agri-2019-0002.

MARTINEZ-ROMERO, D. - SERRANO, M. - BAILEN, G - GULLEN, F. - ZAPATA, P.J. - VALVERDE, J.M. - CASTILLO, S. - FUENTES, M. - VALERO, D. 2008. The use of a natural fungicide as an alternative to preharvest synthetic fungicide treatments to control lettuce deterioration during postharvest storage. In Postharvest Biology and Technology, vol. 47, no. 1, pp. 54-60. DOI: 10.1016/j. postharvbio.2007.05.020.

MASUNGA, R.H. - UZOKWE, V.N. - MLAY, P.D. - ODEH, I. - SINGH, A. - BUCHAN, D. - DE NEVE, S. 2016. Nitrogen mineralization dynamics of different valuable organic amendments commonly used in agriculture. In $A p-$ plied Soil Ecology, vol. 101, pp. 185-193. DOI: 10.1016/j. apsoil.2016.01.006.

MDITSHWA, A. - MAGWAZA, L.S. - TESFAY, S.Z. - MBILI, N. 2017. Postharvest quality and composition of organically and conventionally produced fruits: A review. In Scientia Horticulturae, vol. 216, pp. 148-159. DOI: 10.1016/j.scienta.2016.12.033.

MEENA, M.D. - JOSHI, P.K. - JAT, H.S. - CHINCHMALATPURE, A.R. - NARJARY, B. - SHEORAN, P. - SHARMA, D.K. 2016. Changes in biological and chemical properties of saline soil amended with municipal solid waste compost and chemical fertilizers in a mustard-pearl millet cropping system. In Catena, vol. 140, pp. 1-8. DOI: 10.1016/j.catena.2016.01.009.

MONDAL, N.K. - DATTA, J.K. - BANERJEE, A. 2015. Integrated effects of reduction dose of nitrogen fertilizer and mode of bio-fertilizer application on soil health under mung bean cropping system. In Communication in Plant Science, vol. 5, no. $1 / 2$, pp. $15-22$.

MONTEMURRO, F. - FERRI, D. - TITTARELLI, F. - CANALI, S. - VITTI, C. 2010. Anaerobic digestate and onfarm compost application: Effects on lettuce (Lactuca sativa L.) crop production and soil properties. In Compost Science \& Utilization, vol. 18, no. 3, pp. 184-193. DOI: 10.1080/1065657X.2010.10736954.

MURAKAMI, K. - HARA, M. - KONDO, T. - HASHIMOTO, Y. 2011. Increased total nitrogen content of poultry manure by decreasing water content through composting processes. In Soil Science and Plant Nutrition, vol. 57, no. 5, pp. 705-709. DOI: 10.1080/00380768.2011.616856.

MUYMAS, P. - PICHYANGKURA, R. - WIRIYAKITNATEEKUL, W. - WANGSOMBOONDEE, T. - CHADCHAWAN, S. - SERAYPHEAP, K. 2015. Effects of chitin-rich residues on growth and postharvest quality of lettuce. In Biological Agriculture \& Horticulture, vol. 31, no. 2, pp. $108-117$.

OLIVEIRA, M. - VIÑAS, I. - USALL, J. - ANGUERA, M. - ABADIAS, M. 2012. Presence and survival of Escherichia coli O157: $\mathrm{H} 7$ on lettuce leaves and in soil treated with contaminated compost and irrigation water. In International Journal of Food Microbiology, vol. 156, no. 2, pp. $133-140$.

PAOLETTI, F. 2015. Chemical composition of organic food products. In KEUNG CHEUNG, P.CH. - MEHTA, B.M. (Eds.), Handbook of Food Chemistry. Springer, Berlin, Heidelberg, pp. 1-25. DOI: 10.1007/978-3-642-416095 23-1.

PRADEEPKUMAR, T. - BONNY, B.P. - MIDHILAA, R. JOHNC, J. - DIVYA, M.R. - ROCH, C.V. 2017. Effect of organic and inorganic nutrient sources on the yield of selected tropical vegetables. In Scientia Horticulturae, vol. 224 , pp. $84-92$.
REGANOLD, J.P. - ANDREWS, P.K. - REEVE, J.R. - CARPENTER-BOGGS, L. - SCHADT, C.W. - ALLDREDGE, J.R. - ROSS, C.F. - DAVIES, N.M. - ZHOU, J. 2010. Fruit and soil quality of organic and conventional strawberry agroecosystems. In PLoS One, vol. 5, no. 9, e12346.

RICO, D. - MARTIN-DIANA, A.B. - HENEHAN, G.T.M. FRIAS, J.M. - BARRY-RYAN, C. 2006. Effect of ozone and calcium lactate treat- ments on browning and textured properties of fresh-cut lettuce. In Journal of the Science of Food and Agriculture, vol. 86, no. 13, pp. 2179-2188. DOI: $10.1002 /$ jsfa.2594.

ROWSE, T. 1981. Culture and democracy: the economists and the performing arts. In ALLEN, J. - FREELAND, A. - GAME, P. - PATTON, C. - MEREWETHER, R. -POOLE, R. - PRINGLE, S. ROSEWARNE AND S. WALPOLE (Eds.), Media Interventions. Sydney: Interventions Publications, 24, 43.

RUTKOWSKA, B. - SZULC, W. - SOSULSKI, T. STĘPIEŃ, W. 2014. Soil micronutrient availability to crops affected by long-term inorganic and organic fertilizer applications. In Plant Soil and Environment, vol. 60, no. 5, pp. 198-203. DOI: 10.17221/914/2013-PSE.

SANTOS, F.T. - GOUFO, P. - SANTOS, C. - BOTELHO, D. - FONSECA, J. - QUEIRÓS, A. - COSTA, M.S. - TRINDADE, H. 2016.Comparison of five agro-industrial waste-based composts as growing media for lettuce: Effect on yield, phenolic compounds and vitamin C. In Food Chemistry, vol. 209, pp. 293-301. DOI: 10.1016/j.foodchem.2016.04.087.

SHAHID, M. - SHUKLA, A.K. - BHATTACHARYYA, P. - TRIPATHI, R. - MOHANTY, S. - KUMAR, A. - LAL, B. -GAUTAM, P. - RAJA, R. -PANDA, B.B. - DAS, B. - NAYAK, A.K. 2016. Micronutrients (Fe, $\mathrm{Mn}, \mathrm{Zn}$ and $\mathrm{Cu}$ ) balance under long-term application of fertilizer and manure in a tropical rice-rice system. In Journal of Soils and Sediments, vol. 16, no. 3, pp. $737-747$

SHEHATA, S.A. - ABDELDAYM, E.A. - ALI, M.R. - MOHAMED, R.M. - BOB, R.I. - ABDELGAWAD, K.F. 2020. Effect of some citrus essential oils on post-harvest shelf life and physicochemical quality of strawberries during cold storage. In Agronomy, vol. 10, no. 10, 1466. DOI: 10.3390/agronomy 10101466.

SHEHATA, S.A. - ABDELGAWAD, K.F. - EL-MOGY, M.M. 2017. Quality and shelf-life of onion bulbs influenced by biostimulants. In International Journal of Vegetable Science, vol. 23, no. 4, pp. 362-371.

SHEHATA, S.A. - EL-MOGY, M.M. - MOHAMED, H.F.Y. 2019. Postharvest quality and nutrient contents of long sweet pepper enhanced by supplementary potassium foliar application. In International Journal of Vegetable Science, vol. 25, no. 2, pp.196-209.

TARTOURA, K.A. - YOUSSEF, S.A. - TARTOURA, E.S.A. 2014. Compost alleviates the negative effects of salinity via up-regulation of antioxidants in Solanum lycopersicum L. plants. In Plant Growth Regulation, vol. 74 , no. 3, pp. $299-310$.

TRINCHERA, A. - LEITA, L. - SEQUI, P. 2006. Metodi di analisi per i fertilizzanti. Ministero delle Politiche Agricole Alimentari e Forestali, Roma.

TUDELA, J.A. - MARÍN, A. - MARTÍNEZ-SÁNCHEZ, A. - LUNA, M.C. - GIL, M.I. 2013. Preharvest and postharvest factors related to off-odours of fresh-cuticeberg lettuce. In Postharvest Biology and Technology, vol. 86, pp. $463-471$. DOI: 10.1016/j.postharvbio.2013.07.028. VIACAVA, G.E. - GOYENECHEA, R. - GOÑIA, M.G. 
- ROURAA, S.I. - AGÜEROB, M.V. 2018. Natural elicitors as preharvest treatments to improve postharvest quality of Butterhead lettuce. In Scientia Horticulturae, vol. 228 , pp. $145-152$. DOI: $10.1016 /$ j.scienta.2017.10.018.

VWIOKO, E.D. - EL-ESAWI, M.A. - IMONI, M.E. AL-GHAMDI, A.A. - ALI, H.M. - EL-SHEEKH, M.M. - ABDELDAYM, E.A. - AL-DOSARY, M.A. 2019. Sodium azide priming enhances waterlogging stress tolerance in okra (Abelmoschus esculentus L.) In Agronomy, vol. 9, no. 11, 679. DOI: 10.3390/agronomy9110679. ZHEN, Z. - LIU, H. - WANG, N. - GUO, L. - MENG, J. - DING, N. - WU, G. - JIANG, G. 2014. Effects of manure compost application on soil microbial community diversity and soil microenvironments in a temperate cropland in China. In PLoS ONE, vol. 9, no. 10, e108555.DOI: 10.1371/journal.pone.0108555.

Received: September 3, 2020 Accepted: October 29, 2020 